NBER WORKING PAPER SERIES

\title{
THE INTERGENERATIONAL EFFECTS OF A LARGE WEALTH SHOCK: WHITE SOUTHERNERS AFTER THE CIVIL WAR
}

\author{
Philipp Ager \\ Leah Platt Boustan \\ Katherine Eriksson \\ Working Paper 25700 \\ http://www.nber.org/papers/w25700 \\ NATIONAL BUREAU OF ECONOMIC RESEARCH \\ 1050 Massachusetts Avenue \\ Cambridge, MA 02138 \\ March 2019, September 2019
}

Thanks to the many seminar and conference audiences, including (in chronological order): NBER Cohort Studies, Economic History Association, Australian National University, All-UC Economic History, UC-Merced, UC-San Diego, Princeton, New York University, Ohio State, Boston University, Pittsburgh, Columbia, George Washington, Chicago Booth, NBER Development of the American Economy, Maryland, UVA, Rutgers, CUNY and Yale Law School. We benefitted tremendously from the comments of Eli Berman, Marianne Bertrand, Sandra Black, Hoyt Bleakley, Michael Bordo, Bruno Caprettini, Bill Collins, Dora Costa, Janet Currie, James Feigenbaum, James Fenske, Joseph Ferrie, Walker Hanlon, Judy Hellerstein, Rick Hornbeck, Melissa Kearney, Henrik Kleven, Wojciech Kopczuk, Ilyana Kuziemko, John LandonLane, David Lagakos, Trevon Logan, Robert Margo, Atif Mian, Suresh Naidu, Giacomo Ponzetto, Nolan Pope, Paul Rhode, Harvey Rosen, Allison Shertzer, Randy Walsh, Owen Zidar and the late Werner Troesken. James Feigenbaum, Matt Jaremski, and Suresh Naidu generously shared data with us for the project. Brian Lee provided excellent research assistance. The views expressed herein are those of the authors and do not necessarily reflect the views of the National Bureau of Economic Research.

NBER working papers are circulated for discussion and comment purposes. They have not been peer-reviewed or been subject to the review by the NBER Board of Directors that accompanies official NBER publications.

(C) 2019 by Philipp Ager, Leah Platt Boustan, and Katherine Eriksson. All rights reserved. Short sections of text, not to exceed two paragraphs, may be quoted without explicit permission provided that full credit, including $(\odot$ notice, is given to the source. 
The Intergenerational Effects of a Large Wealth Shock: White Southerners After the Civil

War

Philipp Ager, Leah Platt Boustan, and Katherine Eriksson

NBER Working Paper No. 25700

March 2019, September 2019

JEL No. J62,N11

\section{ABSTRACT}

The nullification of slave wealth after the U.S. Civil War (1861-65) was one of the largest episodes of wealth compressions in history. We document that white Southern households holding more slave assets in 1860 lost substantially more wealth by 1870 , relative to households that had been equally wealthy before the war. Yet, the sons of former slaveholders recovered relative to comparable sons by 1900 , and grandsons surpassed their counterparts in educational and occupational attainment by 1940 . We find that social networks facilitated this recovery, with sons marrying into other former slaveholding families. Transmission of entrepreneurship and skills appear less central.

\author{
Philipp Ager \\ Department of Business and Economics \\ University of Southern Denmark \\ Campusvej 55 \\ 5230 Odense M, Denmark \\ and CEPR \\ phag@sam.sdu.dk \\ Leah Platt Boustan \\ Princeton University \\ Industrial Relations Section \\ Louis A. Simpson International Bldg. \\ Princeton, NJ 08544 \\ and NBER \\ lboustan@princeton.edu
}

\author{
Katherine Eriksson \\ Department of Economics \\ University of California, Davis \\ One Shields Avenue \\ Davis, CA 95616 \\ and NBER \\ kaeriksson@ucdavis.edu
}




\section{Introduction}

Wealth concentration in the hands of a small but powerful elite contributes to underdevelopment (Engerman and Sokoloff, 1997; 2002). Although wealth inequality is highly persistent, it can dissipate during times of war, revolution or catastrophe (Clark, 2014; Atkinson, Piketty and Saez, 2011; Piketty, 2014; Scheidel, 2017). Are these sudden changes to the distribution of resources long lasting, or do the families that started out ahead before an upheaval return to the top? The answer depends on whether the observed correlations of wealth between parents and children are generated through direct transfers of monetary resources or through investments of correlated inputs, like human and social capital (Becker, Kominers, Murphy and Spenkuch, 2018).

We study this question in the aftermath of the American Civil War (1861-65), a conflict that led to the formal abolition of slavery in the U.S. South. On the eve of the War, the South was a highly unequal society. One metric of inequality, the 90-50 ratio, was 14-1 for white Southerners in 1860, compared to 9-1 in the North, and 12-1 in the U.S. today (Kuhn, Schularick and Steins, 2017). About half of antebellum Southern wealth was held in enslaved persons, although only 21 percent of white Southern households owned any slaves and less than 0.5 percent owned more than 50 slaves (Soltow, 1975). Emancipation led to the total nullification of all slave wealth. As one Georgia planter bemoaned at the war's end, "by our defeat, we have lost [...] millions in the emancipation of our slaves, we have virtually lost [everything]” (Bryant, 1996, p. 113). From 1860 to 1870 , the wealth of white Southern households declined by 38 percent at the median and by 75 percent at the $90^{\text {th }}$ percentile, leading the $90-50$ ratio to fall to $10-1$ by 1870 .

Contemporary studies find that monetary resources in the form of gifts and bequests can account for a large portion of the correlation in wealth between parents and children (Black, Devereux, Lundborg and Majlesi, forthcoming; Boserup, Kopczuk and Kreiner, 2016; Fagereng, Mogstad and Ronning, 2018; Adermon, Lindahl and Waldenstrom, 2018). ${ }^{1}$ In this case, a simple model of intergenerational wealth transmission suggests that a loss of parental resources should dampen investment in children, lowering wealth in the next generation (e.g., Becker and Tomes, 1986). Therefore, family resources should be particularly important in economies that have poorly functioning credit markets, like the post-War U.S. South. Emancipation “virtually wiped out credit

\footnotetext{
${ }^{1}$ Bowles and Gintis (2002) and Black and Devereaux (2011) review the broader literature on the effect of family resources (often income) on children.
} 
markets,” which had been heavily dependent on slave collateral (Ransom, 2005, p. 371; Kilbourne, Jr., 1995; González, Marshall and Naidu, 2017). ${ }^{2}$

Contrary to this framework, we find that white slaveholding families in the South quickly recovered from the loss of material resources due to emancipation, relative to comparably wealthy Southern households with fewer or no slaves, even though the South as a region persistently fell behind the North. This recovery suggests a remarkable persistence of correlated inputs for wealthy Southerners such as ability, specific skills, and social networks. Although we cannot isolate the exact factors that enabled recovery, both qualitative and quantitative evidence (which we describe below) is most consistent with the role of social networks.

Our analysis is based on newly available complete-count digitized Census data, which allows us to follow hundreds of thousands of household heads before and after the war across Census waves. In building our dataset, we take advantage of the slaveholder schedule in 1860 and unique Census questions on wealth holdings from 1850 to 1870. We also use Census linking to follow the children and grandchildren of white Southern household heads to 1900 and 1940.

We use two contrasts to estimate the emancipation wealth shock and its transmission. First, we compare white Southern households whose surnames were, on average, associated with above/below median slaveholdings in their county of residence in 1860 (for example, a high slaveholding surname like Barksdale versus a low slaveholding surname like Bentley). Second, we directly link as many households as possible to the slave schedule of the 1860 Census to compare the trajectory of known slaveholders who held more/fewer slaves. In each case, we control for the exact percentile in the national wealth distribution in 1860 in order to compare households with identical wealth levels in 1860 but different portfolio allocation between slave and non-slave wealth.

To establish a baseline, we consider the decade before the War, following equally wealthy households that held a larger or smaller share of their 1850 assets in the form of slaves forward to 1860. Comparison households may have owned some slaves (but not as many), and instead owned more land, livestock, buildings and structures, agricultural implements, or, in urban areas, merchant and manufacturing capital. In the pre-War decade (1850-60), households with more slave

\footnotetext{
${ }^{2}$ Martin (2010) collected more than 8,000 mortgages in Louisiana, South Carolina and Virginia before the Civil War. 41 percent of these mortgages included slave collateral, and these raised 63 percent of capital.
} 
assets accumulated more wealth by 1860 than their equally wealthy counterparts in 1850 . This pattern is consistent with rapidly growing slave prices, which more than doubled in this decade, appreciating twice as fast as the price of land (Calomiris and Pritchett, 2016).

An entirely different wealth pattern emerges in the decade of the war. Households that held more wealth in the form of slaves in 1860 lost more wealth by 1870 than their equally wealthy counterparts in 1860. Yet, this wealth shock was not transmitted to the next generation. Instead, sons that grew up in slaveholding households caught up to or even surpassed the economic status of sons from comparable households by $1900 .^{3}$ The ascendancy of antebellum slaveholding families in the South was restored by 1940, when the grandchildren of slaveholders were more likely than the grandsons of similar household heads in 1860 to have graduated from high school or college and to hold white collar positions. ${ }^{4}$

The rapid recovery of slaveholders' sons suggests that slaveholding households held some input - beyond monetary resources - that contributed to sons' wealth. These inputs might be entrepreneurial ability, human capital, or social networks. We consider each of these explanations in turn using a mixture of quantitative and qualitative sources. We conclude that inherited ability and entrepreneurial skills are unlikely to explain the recovery of slaveholders' sons. First, our research design is predicated on comparing households with the same wealth levels in 1860, and so it is unlikely that households were very different in ability within wealth percentiles. Second, results are also robust to including surname fixed effects to control for extended family networks and other (unobservable) differences between families. Third, we find similar recovery in urban areas, where comparison households with fewer or no slaves were likely to hold merchant or manufacturing capital, suggesting a similar entrepreneurial capacity.

\footnotetext{
${ }^{3}$ Feigenbaum, Lee and Mezzanotti (2018) find that farm values declined by 20 percent in the counties on Sherman's path and then rebounded, an aggregate pattern of wealth loss and recovery very similar to our individual level analysis. In contrast, Martins, Cilliers, and Fourie (2019) find that the sons of slaveholders in the British Cape Colony (present day South Africa) that received less compensation for the loss of their slave wealth had shorter life spans.

${ }^{4}$ Because the 1900 Census does not include questions about education, we cannot observe whether the sons of slaveholders also received more education. However, it is worth noting that overall school attendance declined for white southerners from around 40 percent in 1860 to 25 percent in 1870, before recovering by 1900, around the time that the grandsons of slaveholders would have been in school (Bleakley and Hong, 2013).
} 
We also think it is unlikely that the sons of former slaveholders inherited the human capital or managerial skills necessary to adapt to the sharecropping system that emerged after slavery. First, the skills needed to oversee slave teams were not the same as those needed for contracting with tenant farmers. Second, the provision of in-kind benefits like protection from violence or other paternalistic arrangements would have only been possible on farms with large slaveholdings (Alston and Ferrie, 1999). However, we document similar patterns of recovery for the sons of both small and large slaveholders, as well as in counties that did not specialize in the cultivation of cotton, where plantation farms were more prevalent.

Instead, we find consistent evidence that slaveholders maintained their social cohesion by marrying within circles of other former slaveholding families. These close social ties facilitated investments in nascent manufacturing ventures and merchant activities even though slaveholders as a group lost wealth. First, our quantitative analysis reveals that the sons of slaveholders married spouses from other former slaveholding families that lost less wealth than their own. Second, social history suggests that marital and other close social ties between slaveholding families facilitated investments in new ventures or shifts into white-collar positions (Billings, 1982; Bryant, 1996). Third, we find that the grandsons of former slaveholders were more likely to engage in whitecollar work by 1940, relative to their counterparts from equally wealthy pre-War backgrounds. In this setting, we find that social position was persistent, even if monetary losses were not. In this way, our results are consistent with Bleakley and Ferrie (2016), who find no intergenerational transmission of wealth acquired by random lottery in the 1832 Georgia land allocation.

The documented pattern of elite recovery is consistent with the theoretical framework of Acemoglu and Robinson (2008), whereby elites invest in alternate mechanisms including new legal systems to maintain control after losing de jure political power. Social cohesion may have facilitated lobbying efforts on the part of former slaveholders to reinscribe the economic power of planters in a post-slave economy, including the passage of crop lien laws prioritizing landowners' claims on tenants' debts, as well as anti-enticement and vagrancy laws designed to reduce labor costs by restricting the mobility of freed slaves (Wiener, 1975; Naidu, 2010). ${ }^{5}$

The Southern economy lagged behind the North for more than 100 years after the Civil War. The final part of our empirical analysis compares wealthy Southerners to Northerners who

\footnotetext{
${ }^{5}$ Ager (2013) shows that the southern elite used their de facto power (as proxied by pre-war relative wealth) to maintain their economic and political status after the Civil War.
} 
had been in the same percentile of the national wealth distribution in 1860; this comparison combines the wartime wealth losses with two regional productivity shocks: the take-off of northern manufacturing and the slowdown in Southern agricultural productivity. We find that, by 1870, all Southerners - even those unlikely to have been slaveholders - held at least 50 percent less wealth than comparably wealthy Northerners, with the size of the wealth loss increasing at higher wealth percentiles. Unlike the within-South analysis, a sizeable portion of the wealth losses of Southern fathers was transmitted to sons and grandsons (around 25 percent by 1900, and 10 percent in 1940). We conclude that the persistence of poor economic outcomes in the South was likely driven by differential productivity shocks in agriculture and manufacturing, not by a compounding effect of the loss of slave wealth.

Our results suggest that the families of slaveholders regained their relative economic status in the South within a generation, despite significant losses of monetary resources. War may be a "great leveler," one of the only forces strong enough to reshape the wealth distribution in the short term (Scheidel, 2017), but established families are able to quickly return to prominence in peacetime. Our results also have important implications for our understanding of American history, undermining the classic view that the Civil War was a major rupture to the Southern elite, and instead providing new and comprehensive evidence of elite resilience (the classic view is due to Woodward, 1951; for revisionist social history, see Wiener, 1975, 1978). ${ }^{6}$

\section{Historical background}

Before the Civil War, the Southern economy was largely agricultural. The region's most fertile soil was dedicated to the cash crops of cotton, tobacco, sugar, and rice, often grown on large plantations, while the upcountry was home to many small subsistence farmers. Slaveholding was reserved for the top echelon of white households. In 1860, 21 percent of white Southern households owned at least one slave and 0.5 percent owned 50 or more slaves (Soltow, 1975). Larger plantations took advantage of economies of scale to achieve efficient production (Fogel and

\footnotetext{
${ }^{6}$ We emphasize that our results contribute to our understanding of the "economic reconstruction" of the post-War South, not to the historiography on political reconstruction (Woodman, 1977). See Foner (1982, p. 84) and Ransom (2005, p. 364-65) on the scholarly shifts from the classic view that political reconstruction was northern "vengeance against a 'prostrate' South" to the midcentury revision that Reconstruction was a "bold [and welcome] effort to create an integrated society" to the post-revisionists who "questioned whether much of importance happened at all."
} 
Engerman, 1974, 1977). ${ }^{7}$ Slave wealth also served as an easily collateralized asset, facilitating the opening of new businesses in urban settings (González, Marshall and Naidu, 2017).

Slave prices increased steadily from 1850 to 1860, betraying no signs that market participants anticipated the coming emancipation. ${ }^{8}$ In general, some traders believed that the country would not resort to violence; others that the South would easily win the war; or that a northern victory would be followed by compensated emancipation (as happened for British slaveholders and for slaveholders in the North). ${ }^{9}$

Enslaved people throughout the South were freed over the course of the Civil War and, outside of the District of Columbia, Southerners were not compensated for the forfeiture of their slave wealth. ${ }^{10}$ Public debate contained a series of proposals to confiscate and redistribute the land of former Confederates, such as the famous " 40 acres and a mule" proposal. Even Andrew Johnson, whose presidency was later known for its "amazing leniency" toward former rebels, initially talked of "confiscating the large estates" (Foner, 1988, p. 183, 190). But, by 1866, the window of opportunity for land reform had closed and most Southerners retained their land after the war (Oubre, 1978; Miller, forthcoming).

Some historians argue that Southern planters remained equally wealthy after the war because their labor costs held steady, despite losing official title to slave ownership (e.g.,

\footnotetext{
${ }^{7}$ Fogel and Engerman (1974, p. 203) describe the slave workforce on large plantations as "rigidly organized as in a factory," with teams separated by task and following an "assembly line” structure from plowing to planting (Metzer, 1975; Fogel and Engerman, 1977; Toman, 2005).

${ }^{8}$ Slave prices peaked in the summer of 1860, falling first with the nomination of Abraham Lincoln as a presidential candidate and then with the outbreak of war activities in April 1861. Calomiris and Pritchett (2016) argue that the decline in slave prices through early 1861 reflected concerns about wartime disruption and taxation, rather than fears about the expropriation of slave property; they rest their argument on the fact that they find no differential price decline for slave children, who would only have become profitable if owned for many years.

9 The Slavery Abolition Act of 1833 in the UK raised 20 million pounds to compensate slaveholders in the British Empire. In the northern states, gradual emancipation plans freed children born into slavery after 25-30 years, far past the age where slave children had compensated their masters for the cost of their upbringing (Goldin, 1973; Fogel and Engerman, 1974).

10 The cost of national emancipation through compensation, rather than through war, would have been very high; the estimated value of all slave wealth was $\$ 2.7$ billion in 1860, more than 50 percent of the annual GDP (Goldin, 1973). Despite these high costs, moderate abolitionists proposed the idea of compensated emancipation many times before the Civil War, only to be rebuffed (Fladeland, 1976). Southerners may have been playing a war of attrition game, holding out for a more attractive deal. Goldin (1973) argues that the North likely chose war over a negotiated settlement because they underestimated the financial and human cost of combat.
} 
Blackmon, 2009). In this view, sharecropping contracts or wage payments were equivalent to slave owners' previous expenses for feeding and housing enslaved workers. We find this reading of history unlikely because, despite efforts like introducing anti-enticements and vagrancy laws after the war, former slave owners were unable to fully restrict the mobility of former slaves. Thus, former owners had to raise compensation above slavery levels in order to induce former slaves to supply labor (Higgs, 1973; Wright, 1986). Furthermore, given that "harsher methods of coercion [were] now no longer available," planters used more attractive contract terms to encourage sharecroppers to supply effort (Shlomowitz 1979, p. 573). Even if labor costs remained at slavery levels, losing title to slave-based wealth would have limited access to credit for slaveholders and their sons by eliminating an important source of collateral.

Consistent with an increase in labor costs or decline in agricultural productivity, land prices fell by 60 percent in the Deep South and by 15 percent in the rest of the South by 1870 (see Appendix Figure 1a). ${ }^{11}$ Total agricultural output per capita fell by nearly 40 percent in the South from 1860 to 1870 (Engerman, 1966; Engerman, 2000, p. 356-361). ${ }^{12}$ The decline in southern agricultural productivity was due in large part to the shift from the supervised gang labor under slavery to tenant farming (Reid, 1973; Ransom and Sutch, 1975; Higgs, 1977). ${ }^{13}$

${ }^{11}$ We define the Deep South to be the five major cotton producing states of Alabama, Georgia, Louisiana, Mississippi, and South Carolina.

12 Cotton production was around 20 percent below pre-war levels circa 1870 (Appendix Figure 1b). As a result, the world price of cotton was high in 1870 (Wright, 1974, 1978). Responding to this price incentive, the share of acres planted in cotton expanded over the 1870s. By the mid1870s, the total cotton harvest had completely recovered and began expanding (Olmstead and Rhode, 2008). Cotton yields per acre remained unchanged until the 1930s; instead, the growth in cotton production was entirely driven by extensive margin increases in acreage (Appendix Figure 1c).

13 The institution of sharecropping was the outcome of a protracted negotiation during the late 1860s between freedmen, who wanted to cultivate and own their land, and planters, who "sought to preserve the plantation as a centralized productive unit, worked by laborers in gangs" (Wiener, 1978, p. 35). On their side, freedmen held out by refusing to sign contracts, withholding their labor and organizing politically (see Logan, 2018 on the efficacy of black politicians during Reconstruction). On the other side, planters lobbied for the passage of laws to restrict black mobility and bargaining power (the "Black Codes"), and also enlisted the Ku Klux Klan and other vigilante groups to terrorize black workers (see Naidu, 2010 on vagrancy and anti-enticement laws). Wiener (1978, p. 66) concludes that the abandonment of gang labor in favor of sharecropping "was a major concession to the freedmen." In the five major cotton states, the percent of land in plantation-sized farms (500+ acres) fell from one-third to just 11 percent from 1860 to 1870 (Ransom and Sutch, 1977, p. 71). 
In the aggregate, the Civil War and its aftermath led to a major compression of the wealth distribution in the South. Table 1 presents descriptive statistics for the wealth holdings of white household heads in 1860 and 1870 by region. Before the war, white households in the South were wealthier than their counterparts in the North at every point in the distribution. Wealth holdings were 25 percent higher at the median and more than 100 percent higher at the $90^{\text {th }}$ percentile. Wealth in the South fell substantially at every percentile from 1860 to 1870, while remaining steady or falling slightly in the North, primarily due to price deflation in that decade (Martin, 2017). Thus, by 1870, the southern wealth advantage had become a wealth penalty. Wealth declines in the South were largest for the rich, leading to a major compression of the wealth distribution. The 90-50 ratio of wealth holdings fell from 14-to-1 in 1860 to 10-to-1 in 1870, while the 90-50 ratio in the North remained unchanged at around 9-to-1.

Although the South as a whole experienced substantial wealth compression after the war, the effect of the Civil War on the Southern planter elite remains an active debate. Did war and emancipation lead formerly wealthy planters to lose their prominent place at the top of the wealth distribution?

The classic view of the postwar South is that emancipation was a major rupture to the region's wealthy elite. C. Vann Woodward, the leading mid-century historian of the postwar South, argued that "no ruling class of our history ever found itself so completely stripped of its economic foundations as did that of the South in this period...[including] the leading financial, commercial, and industrial families of the region” (Woodward, 1951, p. 29). As evidence, Woodward (1951, p. 152) cites Mitchell's (1921) study of 254 Southern industrialists in the late nineteenth century, which concludes that "about eighty per cent [of new wealth in the South] came of non-slaveowning parentage." ${ }^{14}$ In related recent work, Dupont and Rosenbloom (2018) link wealthy households in the 1870 Census back to 1860 . They find substantially more turnover at the top of the wealth distribution in the South than in the North over the war decade.

\footnotetext{
${ }^{14}$ Later on, historians suggested that Woodward meant that planters did not survive the war as $a$ class, rather than as individual families. Wright (1986), for example, emphasizes that southern planters transformed "from laborlords into landlords," a transition that required major shifts in their class interests even if the same families were participating in the post-War economy. Yet, Woodward himself seems to have meant quite literally that large slaveholding families lost their prominent place after the Civil War.
} 
More recent historical studies argue instead that, in many cases, slaveholding families recovered quickly, often by joining the industrial and merchant elite. Our broad analysis of white households throughout the U.S. South complements these small-scale studies of specific locations. Wiener $(1975,1978)$ follows more than 200 wealthy planters in western Alabama across Census waves. He finds no difference in the probability that a family remained in the local elite in the decades before and after the war and concludes that "what occurred... was not the 'downfall' or 'destruction' of the old planter class, but rather its persistence and metamorphosis” into plantermerchants who subdivided their land and extended credit to tenant farmers.

\section{Creating matched samples and defining slaveholding}

We provide new evidence on the trajectory of Southern households after the Civil War with newly available complete-count historical Census data. Our dataset consists of household heads and their sons observed in the 1860 Census, which was taken on the eve of the Civil War, who are then linked either to the 1870 Census (household heads) or to the 1900 Census (sons). We also compile a linked sample of the grandsons of 1860 household heads by linking the male children of matched sons observed in 1900 forward to 1940. For a subset of our sample, we can observe slaveholding directly via matches to the 1860 slave schedule. More broadly, we create a measure of likely slaveholder status by associating household heads with the average slaveholding for their surname and county in the 1860 slave schedule. We define comparison groups based on a household's exact percentile in the 1860 national wealth distribution. We then estimate the effect of exposure to the Civil War wealth shock on the 1870 wealth of a household head, on a proxy for the 1900 wealth levels of sons based on occupation and county of residence, and on a series of economic outcomes for grandsons in 1940.

\section{A. Census linking}

Our main linked sample is created by matching the complete-count digitized Census of 1860 to the Censuses of 1870 (household heads) and 1900 (sons). We use the iterative matching procedure pioneered by Ferrie (1996) and fully automated by Abramitzky, Boustan, and Eriksson (2012, 2014) but we also consider robustness to alternative algorithms.

We start with the complete Census of 1860, which includes around 976,000 white Southern household heads between the ages of 15 and 75, and 1.75 million of their sons aged 0 to 18 in 
1860. Matches are conducted by first name, last name, age and state of birth; we exclude cases with only a first initial. We match around 200,000 household heads forward to the 1870 Census and 350,000 sons to the 1900 Census. We then follow 130,000 sons observed in our linked 1900 households to the 1940 Census (grandsons of the original 1860 household heads). Our final analysis sample is smaller because we focus on households above the median of the 1860 wealth distribution who have enough wealth to have plausibly purchased one slave. The average price of one slave in 1860 was $\$ 800$, or the equivalent of around $\$ 25,000$ today (Williamson and Cain, 2019). Holding $\$ 800$ placed a household at the $55^{\text {th }}$ percentile of the national wealth distribution in 1860 .

Our match rates of around 20 percent from the 1860 Census to either 1870 or 1900 is standard for Census-based linking in the nineteenth century, due to factors like the widespread use of first initials, rather than complete names, on Census manuscripts, and the old-fashioned handwriting that can lead to transcription errors in the digitization process (see, for example, Bleakley and Ferrie, 2016; Salisbury, 2017; Eli, Salisbury and Shertzer, 2018). Abramitzky, et al. (2019) document that, even in more recent Census files (=1940), the maximum match rate is around 50 percent, particularly due to the prevalence of common names that cannot be distinguished within year of birth/ state of birth cells.

One concern with Census linking is that individuals may be matched to the wrong person with similar attributes. We present results using a more conservative matching strategy that requires individuals to be unique by name and state of birth within a five-year age band. This conservative procedure is roughly as successful at reducing the "false positive" rate as are a series of more computationally-intensive matching approaches (Bailey et al., 2017; Abramitzky et al., 2019).

Another concern with Census linking is that unique matches are more likely to be made between two Census points for men who have an uncommon name or who were numerate and were thus able to report an accurate age on the Census form. Men with these characteristics may have higher socio-economic status than the general population. Appendix Table 1 compares men in our matched sample to white southern household heads in the 1860 Census who cannot be matched forward. Men in the linked sample were 5 percentage points (10 percent) more likely to be farmers in 1860 and 6 percentile ranks higher in the 1860 wealth distribution. To improve external validity to the full population, our main results are reweighted by these baseline 
characteristics. Column 3 in Appendix Table 1 demonstrates that the reweighting procedure substantially balances the matched sample with the unmatched segment of the population. ${ }^{15} \mathrm{We}$ report unweighted results in the appendix.

A concern specific to this context is that all matched individuals must have survived the Civil War. Most soldiers were between the ages of 18 and 39, but it has been reported that children as young as 12 participated in the war. The typical father in the data was 40 years old in 1860 and the typical son was 13 years old by 1865, suggesting that most fathers were too old to have served in the war and most sons were too young. ${ }^{16}$ Results are robust to excluding the youngest fathers and oldest sons who are most likely to have served, as reported in the appendix.

\section{B. Measuring slaveholder status}

We classify a household's slaveholding status in two ways. Our first measure is an indicator of "likely slaveholding" that can be calculated for the full linked sample and our second measure requires matching individual household heads to the 1860 slave schedules directly.

To identify likely slaveholders, we start by defining surnames that, on average, were associated with slave ownership. A "slaveholder surname" is a surname $j$ whose average slaveholding in the 1860 slave schedule was above the median value for their county of residence $c$ in $1860\left(N_{j c}>\right.$ median). ${ }^{17}$ We then interact having a slaveholder surname with percentiles of the 1860 wealth distribution. Household heads at the median of the wealth distribution were unlikely to be slaveholders, regardless of their surname (a fact that we will document in Figure 1 below). Thus, we focus our attention on household heads above the $75^{\text {th }}$ percentile who had slaveholder surnames and classify them as "likely slaveholders," although we always show results for all

\footnotetext{
${ }^{15}$ Coefficients in column 2 are weighted by the propensity of being matched $\mathrm{P}_{i}\left(\mathrm{M}_{i}=1 \mid \mathrm{X}_{i}\right)$, which is calculated from a probit of match status on the covariates (e.g., age, farm status). Observations are reweighted by $\left(1-\mathrm{P}_{i}\left(\mathrm{M}_{i}=1 \mid \mathrm{X}_{i}\right)\right) / \mathrm{P}_{i}\left(\mathrm{M}_{i}=1 \mid \mathrm{X}_{i}\right) \times q /(1-q)$, where $q$ is the proportion of records linked.

${ }^{16}$ Hall, Huff and Kuriwaki (forthcoming) find that men who owned slaves in 1850 were more likely to have sons that served in the Civil War, which they speculate is due to greater identification with the Confederate cause.

${ }^{17}$ Average slave ownership by surname and county is derived from two components in the data: (a) $\mathrm{n}_{j c}$ is the mean number of slaves for surname $j$ in county $c$, conditional on being a slaveholder, which we calculate directly from the slaveholder schedule, and (b) $p_{j c}$ is the probability of being a slaveholder, which is defined as the ratio of households with surname $j$ in county $c$ in the slave schedule and the population census.
} 
percentiles above the median. The distribution of average slaveholding by surname and county throughout the South is presented in Appendix Figure 2. By this measure, the median surnamecounty pair was associated with ownership of less than one slave. There is a long right tail above the median, reflecting the skewed distribution of slaveholding.

Our second measure of slaveholding is based on direct links of households in our sample to the 1860 slave schedule. We start by linking the complete digitized 1860 slave schedule (430,000 slaveholders) to the full 1860 population census by first name, last name, and county of residence in 1860, while also requiring a plausible amount of reported wealth to be a slaveholder. ${ }^{18}$ Despite the fact that the population and slave schedules were collected at the same time (and often by the same enumerator), we are only able to match 32 percent of the full slave schedule to the population census, primarily because of common names and the use of first initials, rather than full first name. ${ }^{19}$ Furthermore, the slave schedule does not contain other personal characteristics about individuals (e.g., ages, other household members) that could be used to confirm matches. We find 140,000 slaveholders in the full 1860 population census; of these, around 20,000 are in our 1860 to 1870 linked dataset. ${ }^{20}$ We supplement these automated links with a hand-constructed dataset of the richest slaveholders linked to the 1860 slave schedule compiled by Ager (2013) to address the fact that the largest slaveholders often held slaves in multiple counties. ${ }^{21}$

\footnotetext{
${ }^{18}$ In particular, we block on county and first letter of each name and calculate Jaro Winkler string distances between the population and slave schedules for each possible match. To find an actual match, we exclude any possibilities with a Jaro Winkler score below 0.8 . We also exclude as implausible any matches in which personal wealth in the Census of Population is less than $\$ 400 \mathrm{x}$ the number of slaves in the slave schedule. If we are then left with a unique match, we consider the observation to be linked.

${ }^{19}$ We are able to match 47 percent of slaveholders who have a full first name, rather than just a first initial, to the population schedule, which is close to the matching ceiling established by Abramitzky, et al. (2019). This paper attempts to match two versions of the 1940 Census that were transcribed separately but for which "true" matches can be established through manuscript and line number. Linking by first and last name, age and state of birth only achieves a match rate of 50 percent because of common names and transcription error.

${ }^{20}$ There are two reasons for a failure to match to the slave schedule: (1) the household may not have owned any slaves or (2) the household may have owned slaves but cannot be found in the slave schedule due to transcription errors. Therefore, we cannot treat non-matches as nonslaveholders, and so this analysis will be entirely on the "intensive margin" (comparing slaveholders that owned more versus fewer slaves).

${ }^{21}$ Results are robust to excluding these cases from our linked samples (less than 1 percent of our sample).
} 


\section{Outcome variables for fathers and sons}

Our main outcome variables are 1870 household wealth (for fathers) and 1900 occupationbased wealth (for sons). The 1870 Census was the last Census to ask all household heads to report total dollar value of real estate and personal wealth. Thus, for sons in 1900, we rely on a proxy for wealth based on occupation and county of residence. For grandsons, we use all standard Census outcomes in 1940, including highest grade attended, wage and salary income, occupational choice, and occupation score. Summary statistics for these outcome measures are presented in Appendix Table 2.

One concern with the 1870 wealth data is the extent of non-reporting and the fact that blanks cannot be distinguished from true zeroes (Steckel, 1994). Appendix Figure 3 shows that the probability of reporting blank/zero wealth in 1870 declines linearly with 1860 wealth until the $60^{\text {th }}$ percentile. Beyond the $60^{\text {th }}$ percentile, the probability of reporting blank/zero wealth remains flat at 10 percent. We read this pattern as suggesting that blank fields primarily represent (a declining share of) true zeroes up to the $60^{\text {th }}$ percentile, but thereafter are primarily non-reports; otherwise, surely the probability of true zeroes would continue falling with 1860 wealth levels above the $60^{\text {th }}$ percentile. Because our focus is on likely slaveholders above the $55^{\text {th }}$ percentile, we drop all observations with blank wealth fields (likely non-reporters) from the main analysis (12.65 percent of the data), but assess robustness to this choice in Section IV.

For sons in 1900, we follow Collins and Zimran (2018) in creating a wealth proxy using occupation and county/state of residence. In particular, we match agricultural occupations to median 1870 wealth by occupation-county cell and non-agricultural occupations to occupationstate cell. To validate this measure, we compare results for our father sample in 1870, for which we have both individual wealth data and this occupation-based wealth proxy. One benefit of occupation-based wealth is that it is a reasonable proxy for average lifetime wealth, rather than wealth at a particular age or in a single year.

Later in the paper, we also use a proxy for the likely family background of a son's spouse (for those who are married with spouse present in 1900). Following Olivetti and Paserman (2015), we link sons to their likely father-in-laws by calculating the characteristics of fathers who had daughters of a given first name, state of birth, and cohort of birth (in five-year bands) living in their household in either 1860 or 1870 . We then assign these attributes to wives with the same name and year/state of birth in the 1900 data. We are interested in using the social position of sons’ 
spouses to learn about the importance of social networks in recovery from the emancipation wealth shock, and so we measure three aspects of father-in-law's wealth: share of estate made up of personal property in 1860 (a measure of likely slaveholding); logarithm of wealth in 1860 and 1870 (wealth holdings before and after the war).

\section{Transmission of the Civil War wealth shock for likely slaveholders}

\section{A. Estimating equation}

Our goal is to estimate the effect of the wealth shock associated with slaveholding on the subsequent socio-economic status of white Southern households across three generations. Our first empirical approach is to compare households with surnames that were more/less associated with slaveholding at various points in the initial (1860) wealth distribution. For each outcome of interest, we estimate:

$$
Y_{i j s p}=\alpha_{s}+\eta_{p}+\left[\mathrm{I}(\text { Slaveholder Surname }) \times V E N T I L E 1860_{i}\right] \Gamma+\mathrm{X}_{\mathrm{i}} \Theta+\varepsilon_{i j s p}
$$

for household $i$ with surname $j$ living in state $s$ in percentile $p$ of the 1860 national wealth distribution. The outcome variables $Y_{i j s p}$ include: (1) an indicator for household $i$ matching to the 1860 slave schedule (to confirm differences in actual slaveholding), (2) the logarithm or percentile rank of father (son) wealth in 1870 (1900), and (3) a series of economic measures for grandsons in 1940.

Our main right-hand side variables of interest are interactions between indicators for having a slaveholder surname and a household's ventile in the 1860 wealth distribution [I(Slaveholder Surname $j) \times$ VENTILE1860 $i$. The coefficients $\Gamma$ compare households with a slaveholder surname to similarly wealthy counterparts without a slaveholder surname. We control for the main effect of 1860 wealth with a set of dummy variables for the exact percentile in the wealth distribution $\left(\eta_{p}\right)$. Note that the ventile interactions fully span the main effect of having a slaveholder surname.

Because slaveholding was more common in the Deep South, we control for a set of state fixed effects $\left(\alpha_{s}\right)$. We also control for a quadratic in age for fathers and quadratics in own age and father's age in 1860 for sons $\left(\mathrm{X}_{i}\right)$. In some specifications, we also add surname fixed effects, which captures any socio-economic differences between surnames beyond the probability of 
slaveholding (e.g., because some last names are associated with immigration from particular regions or specific family dynasties; see, for example, Clark (2014)).

\section{B. Fathers and sons in likely slaveholding families: 1870 and 1900}

Figure 1 documents that having a slaveholder surname is correlated with two measures of likely slaveholding, especially for households above the $80^{\text {th }}$ percentile of the wealth distribution. The first measure (Panel A) is an indicator equal to one if the household itself matches to the 1860 slave schedule, which enumerated all slaveholders. The second measure (Panel B) is the share of total wealth in 1860 made up of "personal property." Personal property includes the value of slaves, but also agricultural implements, shop inventory, financial assets, jewelry and furniture, etc. We see little difference in the probability of matching to the slave schedule (or share of wealth made up of personal property) by slaveholder surname between the $50^{\text {th }}$ and $65^{\text {th }}$ percentiles, and then a rising relationship between these indicators and slaveholder surname thereafter. At the $90^{\text {th }}$ percentile of the wealth distribution, households with slaveholder surnames were twice as likely to match to the slave schedule ( 20 percentage points, on the basis of a 20 percent match rate), and had 10 percentage points more of their assets in personal property (on a basis of 40 percent).

To establish a baseline for our postwar wealth analysis, we begin by considering the relationship between slaveholder surname and wealth creation in the 1850s, the decade before the Civil War broke out. Slave prices doubled during this decade, rising faster than other assets, and so we expect here to see that slaveholding households accumulated more wealth by 1860 than their similarly-wealthy counterparts (Williamson and Cain, 2019). Figure 2 indeed documents that, for households above the national median wealth level in 1850, those with slaveholding surnames accumulated more wealth by 1860 - gaining 30-50 log points below the $80^{\text {th }}$ percentile, and 50-80 $\log$ points above the $80^{\text {th }}$ percentile, relative to comparable wealthy households without a slaveholding surname.

The pattern of wealth creation is entirely different in the decade of the Civil War. Figure 3 (Panel A) considers the wealth of household heads in 1870, five years after the war's end. We see no difference between household heads by slaveholder surname up to the $75^{\text {th }}$ percentile. From the $80^{\text {th }}$ percentile onward, we document lower wealth levels for household heads with slaveholder surnames, maximized at a $15 \log$ point wealth deficit at the $95^{\text {th }}$ percentile. Appendix Figure 4 
documents similar patterns if we replace father's individual wealth in 1870 with our occupationbased proxy of 1870 wealth.

We can consider the magnitude of this wealth gap in the context of Figure 1 (Panel A), which provides a quasi-first stage documenting differences in the probability of being a true slaveholder. At the $95^{\text {th }}$ percentile, households with slaveholder surnames are 20 percentage points more likely to match to the slave schedule (40 percent versus 20 percent). However, given transcription errors and common names that cannot be uniquely matched, Abramitzky et al. (2019) finds that only one in two actual matches can be found in Census linking exercises. Thus, an observed match rate to the slave schedule of 40 percent suggests that, in truth, 80 percent of households with high slaveholder surnames were true slaveholders, compared to 40 percent of households with low slaveholder surnames (at the $95^{\text {th }}$ percentile). The implied 40 percentage point gap in the probability of being a true slaveholder is associated with a 15 percent wealth differential in 1870 (Figure 3), suggesting that each percentage point difference in the likelihood of slaveholding is associated with a 0.38 percent decline in wealth by 1870 (= 15/40). By this logic, slaveholders (percentage $=100$ ) would hold 38 percent less wealth by 1870 than equally wealthy non-slaveholders (percentage $=0$ ).

Despite these large differences in fathers' post-war wealth, Figure 3 (Panel B) does not reveal any difference between sons with slaveholder and non-slaveholder surnames by 1900. If anything, sons with slaveholder surnames whose fathers were in the top 10 percent of the wealth distribution hold 5-15 log points more wealth than sons from similarly wealthy households. Appendix Figure 5 divides sons according to their age on the eve of the Civil War (age 0-7 in 1860/older than 7 in 1860). If father wealth losses prevented households from investing in early childhood health and education, we would expect the recovery process to be slower for sons who were younger in 1860. Yet we find no difference in the extent of son recovery by age at the time of the shock, suggesting that the wealth losses did not diminish human capital acquisition in early childhood.

To put the observed son recovery into context, consider that Alvaredo, Garbinti and Piketty (2017) report that 50 percent of wealth in 1900 was inherited. If parental wealth only affected child wealth via direct investments or transfers of monetary resources, we would expect children to retain around 50 percent of their father's wealth loss in the next generation. Thus, unless slaveholding households were able to invest in their children using other correlated inputs, we 
would expect wealth gaps of at least 5-8 percent for slaveholder sons following their father's wealth losses in 1870 (= $0.50 \times 10-15$ percent loss of father). Yet, our point estimates (except one) are above zero and estimated precisely enough to statistically rule out a wealth gap of 5-8 percent for slaveholder sons. Even our one negative point estimate (for the $85^{\text {th }}$ percentile) would imply a maximum elasticity of son wealth with respect to father wealth of $0.15(=-0.017 /-0.116)$, which is substantially below historical and modern estimates (the range for father-son wealth elasticities is 0.27 to 0.37; see e.g., Kearl and Pope, 1986; Charles and Hurst, 2003; Boserup, Kopczuk and Kreiner, 2016). ${ }^{22}$

Figure 4 instead considers the pattern of Civil War wealth losses and subsequent recovery in terms of father and son's percentile rank in the national wealth distribution, following Chetty, Hendren, Kline and Saez (2014). As in the log specification, we see no difference in the 1870 wealth levels by slaveholder surname up to the $75^{\text {th }}$ percentile of the distribution, at which point slaveholding is unlikely. Thereafter, fathers with slaveholder surnames dropped 1.5-2.0 percentile ranks in the 1870 distribution relative to comparable households. The main difference with the log specification is that wealth losses experienced by the richest fathers in dollar terms were not large enough to change their rank position above the $95^{\text {th }}$ percentile. By 1900 , sons with slaveholder surnames experienced at most a 0.25 rank point decline relative to sons of comparable households, implying a father-son rank-rank slope of at most $0.13(=-0.25 /-1.85)$.

Appendix Figures 6 through 11 document stability of the main results across a number of sensitivity checks. Appendix Figure 6 uses a more conservative linked sample, which requires all matched individuals to be unique by name and place of birth within a five-year age band. This sample is 40 percent smaller but less likely to suffer from false positive matches. Appendix Figure 7 presents unweighted results using the original sample. Appendix Figure 8 drops from the sample any fathers who are young enough (age $\leq 40$ in 1860) sor sons who are old enough (age $\geq 13$ in

\footnotetext{
22 One explanation for the rapid recovery of the sons of the wealthiest slaveholders is that these households were more likely to own slaves outright, rather than borrowing to buy slaves on credit. Kilbourne, Jr. (1995, p. 11) reports that "in the 1850s it was the middle-tier planters who mortgaged their slaves and plantations." After the war, these "middle-tier" households may have been responsible for substantial debt obligations. However, the damage to the southern financial system was so severe that Kilbourne, Jr. (1995, p. 9) writes "those who had purchased slaves before the war on credit were no longer liable for payment to their vendors." We think it is more likely that the sons of more middling slaveholders had weaker connections to the social networks that facilitated recovery (see Section V).
} 
1860) to have been likely to have served in the Civil War. Appendix Figure 9 includes surname fixed effects and Appendix Figure 10 includes county fixed effects. The direction and magnitude of the results are all very similar: we find that fathers with slaveholder surnames held 10-20 percent less wealth by 1870; that the wealth shock was not transmitted to sons in the upper middle class ( $75^{\text {th }}$ to $90^{\text {th }}$ percentile in the 1860 wealth distribution); but that the sons from households at the top of the wealth distribution entirely recovered and surpassed sons from comparable households. ${ }^{23}$

Appendix Figure 12 splits the sample by the history of emancipation activity in the state. Five Southern states in our sample (AR, LA, MD, MO and TN) abolished slavery on their own after the Emancipation Proclamation of 1863 but before the end of the war, often under control of a Union-installed military governor; and slavery ended in Washington, D.C. with the Compensated Emancipation Act in 1862 (Oakes, 2012) ${ }^{24}$ Slavery only ended in the balance of Southern states with the passage of the thirteenth amendment to the US Constitution in December 1865. We find a similar pattern of father wealth loss and son recovery in the two subsamples, but in both the depth of wealth losses and the extent of recovery were larger in the states that were not under military occupation.

\section{Grandsons in likely slaveholding families: 1940}

Does the recovery of slaveholding dynasties continue into the third generation? Figure 5 presents a series of socio-economic outcomes for grandsons from families with high versus low slaveholding surnames. The grandsons of likely slaveholders - that is, men with high slaveholder surname who were above the $80^{\text {th }}$ percentile in the national wealth distribution - were 3-5 percentage points more likely than the descendants of similarly wealthy grandfathers to have at least attended high school (Panel A). Furthermore, grandsons from likely slaveholding families in the top 10 percent of the 1860 wealth distribution were 2-3 percentage points more likely than their

\footnotetext{
${ }^{23}$ We continue to find wealth losses between 5 and 26 log points when including observations with blank/zero wealth (albeit with less precision; see Appendix Figure 11). The one exception is for father wealth losses in the top 5 percent of the 1860 wealth distribution. Results are similar when using inverse hyperbolic sine instead of a logarithm transformation.

${ }^{24}$ West Virginia abolished slavery on its own in the process of becoming a state. However, we combine WV with VA to maintain 1860 geography throughout the analysis. We thank Suresh Naidu for bringing this idea to our attention.
} 
similarly-wealthy counterparts to have attended some college (Panel B). These educational differences are economically significant: fewer than 10 percent of Southern men of age to be in high school in 1910 - the relevant cohort for the grandsons of slaveholders - graduated from high school (Goldin and Katz, 2008). Thus, despite any financial set-back experienced in the 1860s, these families were able to rebuild their capital by 1900 and use these resources to invest in the education of their progeny. Consistent with a higher degree of educational attainment, these grandsons were 2-5 percentage points more likely to hold a white collar position (Panel C). However, we do not observe higher occupation-based income for the grandsons of slaveholders, except for very elite families (the top 5 percent) (Panel D). ${ }^{25}$ We suspect that the occupation score measure, which proxies for income at the occupation level, understates the income of farmers with large landholdings, and so may understate the social position of the grandsons of slaveholders.

\section{Possible mechanisms for wealth recovery}

Standard models of intergenerational transmission suggest that, in an economy with limited access to credit, like the postbellum South, the economic outcomes of sons should be influenced by the material resources of their fathers (Becker and Tomes, 1986). Yet, we find that the sons of slaveholders were able to readily recover by 1900, which implies that slaveholding families were able to draw on other correlated inputs to transmit their advantages, despite the loss of monetary resources (Becker, Kominers, Murphy and Spenkuch, 2018). Although we cannot pinpoint the relevant factors with certainty, we discuss possible mechanisms for recovery in this section. After casting doubt on the possibility that slaveholders transferred ability, entrepreneurial acumen, or specific labor management skills to their sons, we point to the most likely possibility that sons of slaveholders benefited from being embedded in social networks that helped provide capital and employment opportunities in the aftermath of the war.

The first explanation for rapid recovery is that slaveholding fathers were simply endowed with higher ability, which their children then inherited. Barth, Papageorge and Thom (forthcoming) find a strong association between genetic endowment and household wealth at

\footnotetext{
${ }^{25}$ We also see no evidence that that the grandsons of likely slaveholders had higher wage and salary income in 1940 (Appendix Figure 13). Wage and salary information is an incomplete measure of annual earnings because the Census did not ask about business income for farmers and business owners who make up 32 percent of the sample. For this reason, we prefer the occupationbased income measure.
} 
retirement, even after controlling for education and income. We find this account unlikely in our context, given that our results hold even after controlling for surname fixed effects, which capture any characteristics that are shared within extended families, including genetic endowment (Appendix Figure 9).

A second possibility is that household heads that accumulated more slave wealth were more entrepreneurial and passed along their commercial acumen. In rural areas, non-slave assets were primarily land, whereas in urban areas, other assets included industrial or merchant capital, which were also associated with entrepreneurship. Figure 6 reports separate log wealth results for urban and rural areas. ${ }^{26}$ Although rural areas comprise more than 85 percent of the sample, we find that likely slaveholders in urban areas experienced the largest wealth losses, holding up to 35 percent less wealth than comparison households by 1870 (Panel A). Yet, despite these large losses, the sons with slaveholding surnames who were raised in urban areas completely caught up to or surpassed their counterparts by 1900 (Panel B). We think it is likely that there was a balanced endowment of entrepreneurial ability across wealthy slaveholding and non-slaveholding households in Southern cities, yet we continue to find son recovery, suggesting that a distinctive endowment of entrepreneurial ability is not the cause. ${ }^{27}$

A third explanation for son recovery is that former slave owners developed skills of labor coercion and management that were transferrable, if imperfectly, to the system of sharecropping that emerged after the Civil War. We find this possibility unlikely for three reasons. First, it is not clear that large slaveholders had an advantage in designing and implementing sharecropping contracts relative to equally wealthy landholders. As historians explain, "former masters [...] lacked the experience and knowledge necessary to deal with free labor" and had to "learn to be employers” (Woodman, 1977, p. 550). Former slaves did not necessarily continue to work in large numbers on the land of their previous owners; rather, newly freed black workers moved readily to search for better tenancy contracts (Higgs, 1973; Wright, 1986, p. 65). ${ }^{28}$ Second, to the extent that

${ }^{26}$ Following Census definitions, we classify an urban county as one containing at least one town of 2,500 residents or more in 1860 .

${ }^{27}$ Note that all panels are graphed on the same scale, which makes the rural wealth losses look small in comparison, but we still find significant wealth losses and son recovery in the rural sample (Panels C and D).

${ }^{28}$ Despite anti-enticement and vagrancy laws intended to reduce black mobility, Cohen (1991, p. 4) argues that "planters were rarely able to use their legal instruments effectively enough to interdict seriously black movement from one state to another. Throughout the period up to World 
former owners would be able to use non-wage compensation like housing or protection from violence to attract croppers on good terms, these advantages would belong to the largest slaveholders with plantation-style farms. Yet, we find that the sons of slaveholders between the $75^{\text {th }}$ and $94^{\text {th }}$ percentiles recovered as well (although perhaps the benefits of inheriting a plantation could explain the particular success of sons at the very top). Third, Appendix Figure 14 documents that the largest rural wealth losses occurred for fathers in counties that planted below median share of land in cotton (cotton was the main Southern cash crop and was often cultivated by sharecroppers and tenants). Slaveholders in these counties were less likely to rely on sharecropping arrangements, and yet their sons experienced full recovery.

A fourth possibility is that slaveholding households had fewer children after the war, and thus were able to partially compensate for their wealth losses by spreading their inheritance over fewer offspring. Appendix Figure 15 demonstrates that the fertility-based explanation is unlikely. Point estimates suggest that slaveholder households did have more children during the war, before the full extent of wealth losses were known, and fewer children after the war, when losses had been realized. However, the higher fertility during the war and lower fertility after the war offset each other. Furthermore, each of these disparities are economically small and statistically insignificant. Slaveholding families had around 0.02 more children during the war (1861-65) and 0.01 fewer children after the war (1866-1870), on a basis of around 5 children per family by 1870 .

After casting doubt on these alternative explanations, we think the most likely explanation for the rapid recovery of slaveholders' sons is that slaveholding families were embedded in social networks that facilitated adjustments to wartime losses. Because it is challenging to empirically trace out full social networks, we bring both qualitative and quantitative evidence to bear to substantiate this claim.

First, historians argue that slaveholder families used social and marital connections to set up their children in the industrial or mercantile sectors, or as purveyors of credit in the slowly recovering Southern financial system. Billings (1982) documents that, in North Carolina, more than 60 percent of mill owners in the growing textile industry were from prominent planter or agrarian families. The transition from agriculture to industry occurred through social networks: Billings (1982, p. S59) argues that "these were not isolated individuals, but members of a social

War I, blacks in most parts of the South appear to have moved with relatively little interference when jobs were available.” 
class bound together by common interests in plantation agriculture and by an extensive web of social relationships. Landed families were interconnected by marriage and united by business interests.” Bryant’s detailed study of Greene County, Georgia concurs that the "new men' who rose to prominence after the war "were new only in their occupations and generation, for most came from established leading families” (Bryant, 1996, p. 172). One such person, Edward A. Copelan, was a typical example. Copelan, the scion of a prosperous plantation family that "lost their slaves and much of their wealth," decided to leave farming, taking a position as a clerk, and eventually achieving "great success in the mercantile business" (Bryant, 1996, p. 172-173).

Second, we document that the sons of slaveholders were more likely to marry into other slaveholding families, further solidifying bonds within this elite social class. Figure 7 graphs coefficients from a version of equation 1 that uses likely father-in-law's share of estate coming from personal property in 1860 as a measure of his likely slaveholding (Panel A). Relative to sons from comparable households, sons of slaveholders were more likely to marry daughters of men whose estates were weighted toward personal property, rather than real estate, by 1-2 percentage points in 1860. This pattern is especially apparent for sons at the top of the wealth distribution. Although marrying other slaveholders might reinforce social ties, all members of this class also lost resources during the war, which might limit access to capital. We find that the sons of slaveholders marry wives from families that were 5-10 percent wealthier than comparable wives in 1860 (Panel B), but only a few points wealthier, if at all, by 1870 (Panel C). Compared to the fathers' own losses (up to 15 percent), father-in-law losses are substantially smaller, despite coming from the slaveholding class, suggesting that slaveholding families were able to partially compensate for their losses by arranging advantageous marriages within their own circle.

\section{Transmission of the Civil War wealth shock for known slaveholders}

Thus far, we have compared the sons of men who, by virtue of their surname, were more likely to hold slaves, although we have no direct information on a household's own slave ownership. In this section, we instead analyze the subset of our sample that can be linked to the 1860 slave schedule directly. All of the men in this sample owned at least one slave, and so we cannot study the extensive margin between owning slaves or not. Instead, we look at the intensive margin, comparing households with the same wealth levels in 1860 who owned more/fewer slaves. For these known slaveholders, we estimate: 


$$
Y_{i s p}=\alpha_{s}+\eta_{p}+\mathrm{I}\left(S L A V E \_C O U N T 1860_{i}\right) \Pi+\mathrm{X}_{\mathrm{i}} \Theta+\varepsilon_{i s p}
$$

for household $i$ living in state $s$ in 1860 in wealth percentile $p$. As before, $Y_{\text {isp }}$ is the logarithm of 1870 wealth for fathers or the logarithm of our 1900 wealth proxy for sons. Our main right-hand side variables of interest, denoted I(SLAVE_COUNT1860) are indicators for numbers of slaves owned in 1860. The omitted category is one slave, which represents up to the $35^{\text {th }}$ percentile of the slave-owning distribution. Beyond that, we consider ownership of 2-3 slaves, 4-5 slaves and so on. The largest category, representing 4.2 percent of the known slaveholder sample, is ownership of 18 or more slaves, which corresponds to the "plantation-style" agriculture that is stereotypically associated with the South (Fogel and Engerman, 1974). As above, we control for state fixed effects $\left(\alpha_{s}\right)$ and exact location in the 1860 wealth distribution $\left(\eta_{p}\right)$.

Figure 8 documents that fathers who owned more slaves experienced larger wealth losses during the war, but their sons completely recovered by 1900. Fathers that owned 4 to 17 slaves in 1860 held 10 percent less wealth by 1870 than similarly wealthy slaveholding households with only one slave (Panel A). Large slaveholders (fathers with 18 or more slaves) record the largest wealth losses, holding 20 percent less wealth than comparable households with only one slave. Yet, by 1900, all sons completely recovered (Panel B). Point estimates are above or very close to zero, with one exception (sons of men with 9-17 slaves), yet this estimate is not precise enough to be distinguished from zero. Panel C compares the grandsons of known slaveholders by the size of their grandfather's slaveholdings. Like their fathers' generation, the grandsons of large slaveholders enjoyed equal or higher occupation-based income in $1940 .{ }^{29}$

\section{Regional productivity shocks: Comparing the North and South after the War}

Our results suggest that the emancipation wealth shock was not transmitted to the next generation. However, it is well-known that the Southern economy fell behind the rest of the country after the War and convergence took more than a century (Barro and Sala-i-Martin, 1992; Caselli and Coleman, 2001). The relative productivity of Southern agriculture declined after the

\footnotetext{
${ }^{29}$ Results look similar in Appendix Figure 16 if we reweight our known slaveholder sample to reflect the aggregate distribution of slave ownership for the South as a whole (Haines, 2010).
} 
war and the South did not participate as widely in industrialization of the era. Were the postwar productivity losses transferred to the next generation?

We compare the sons and grandsons of equally wealthy households in the North and in the

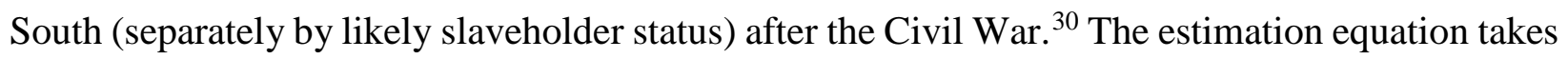
the following form:

$\mathrm{Y}_{i p}=\eta_{p}+\left(\right.$ South $\left._{i} \times \operatorname{VENT1860}_{i}\right) \Psi_{1}+\left(\right.$ South $_{i} \times$ Slaveholder Surname $\left._{j} \mathrm{x} V_{\text {VENT1860 }}\right) \Psi_{2}+X_{\mathrm{i}} \Delta+\varepsilon_{i p}$

with $Y_{i p}$ being the logarithm of 1870 wealth for fathers, the 1900 wealth proxy for sons, and the 1940 occupation score (income proxy) for grandsons. Our right-hand side variables of interest are two sets of interactions: one vector interacting an indicator for living in the South in 1860 with dummy variables for initial ventile of the national wealth distribution, and the other interacting these variables with an indicator for having a likely slaveholder surname. As before, $\eta_{\mathrm{p}}$ controls for a household's initial percentile in the national wealth distribution. The coefficients $\Psi_{1}$ thus compares likely non-slaveholding Southern households to similarly wealthy northern households after the war, and the sum of $\Psi_{1}+\Psi_{2}$ compares likely slaveholding Southern households to their counterparts in the North.

The first panel of Figure 9 documents the extraordinary wealth losses in the South associated with the war. Up to the $65^{\text {th }}$ percentile of the national wealth distribution, nonslaveholding Southern households held around 50 log points less wealth by 1870 than similarly wealthy northern counterparts. Thereafter, losses increased in a log-linear fashion, maximized at $95 \log$ points for households above the $95^{\text {th }}$ percentile. These wealth losses primarily reflect large declines in Southern agricultural productivity, reflected in the price of land. Wealth losses were even larger for likely slaveholders in the South, maximized in the $95^{\text {th }}$ percentile at 130 log points.

Wealthy Southern sons and grandsons made up a substantial amount of ground, but remnants of the original shock remained, even by 1940. In 1900, Southern sons of likely nonslaveholders retained wealth losses of 13-30 log points (around 30 percent of their father's loss) and, by 1940, earned 6-10 percent less than their counterparts in the North (around 15 percent of their grandfather's loss). Yet, while the overall Southern penalty remained nearly a century after

\footnotetext{
${ }^{30}$ We are combining our main linked sample with a comparison sample of northern households that had at least $\$ 800$ wealth reported in 1860 .
} 
the war, the additional disadvantage faced by slaveholders dissipated by the son's generation, suggesting that the productivity losses were more important and persistent than the initial wealth losses.

\section{Conclusions}

The aftermath of the American Civil War led to one of the largest wealth compressions in history. Following the abolition of slavery, former slave owners lost all wealth that had been held in the form of slaves, and civil and political rights were reassigned to the former enslaved population. In addition, Southern land holdings declined substantially in value, especially in areas that had relied heavily on slave labor.

Yet, despite these large wealth losses for white Southern households, we find that pre-Civil War wealth and social status persisted, particularly among the elite. Our evidence is based on newly-digitized complete-count Census samples linked to the 1860 slave schedules and linked forward to sons in 1900 and grandsons in 1940. In particular, we find that despite the fact that likely/known slaveholders experienced substantial wealth losses, their sons had completely recovered relative to similarly-wealthy Southern households by 1900 and their grandsons had surpassed their counterparts in educational and occupation attainment. The combination of wealth losses and productivity declines in Southern agriculture was strong enough to persistently disadvantage wealthy Southerners relative to their northern counterparts, but even this gap had substantially dissipated by 1940 .

Our results speak to the interpretation of intergenerational wealth correlations between fathers and sons. Material resources may matter in some contexts but, in our case, the loss of family wealth did not ultimately affect sons' wealth or income. Sons of wealthy fathers were able to bounce back through the transmission of other advantages, which may have been access to social networks. Our finding of elite recovery is in line with models that predict elite persistence despite fundamental changes in economic relations and political institutions (Acemoglu and Robinson, 2008). Although every historical episode is specific, the loss of wealth of Southern slaveholders rivaled the losses of wealthy households in Germany after World War I, in the United States, the United Kingdom and France during the Great Depression, and even Chinese and Russian elites

after the Communist revolutions. We find that, in the case of the U.S. South, such large wealth losses at the very top can be temporary, resulting in recovery within a single generation. 


\section{References}

Abramitzky, Ran, Leah Platt Boustan, and Katherine Eriksson. 2012. "Europe’s Tired, Poor,Huddled Masses: Self-Selection and Economic Outcomes in the Age of Mass Migration.” American Economic Review, 102(5): 1832-1856.

Abramitzky, Ran, Leah Platt Boustan, and Katherine Eriksson. 2014. "A Nation of Immigrants: Assimilation and Economic Outcomes in the Age of Mass Migration.” Journal of Political Economy, 122(3): 467-506.

Abramitzky, Ran, Leah Platt Boustan, Katherine Eriksson, James Feigenbaum, and Santiago Pérez. 2019. “Automated Linking of Historical Data.” NBER Working Paper 25285.

Acemoglu, Daron, and James A. Robinson. 2008. "The Persistence and Change of Institutions in the Americas.” Southern Economic Journal, 75(2): 282-299.

Adermon, Adrian, Mikael Lindahl, and Daniel Waldenström. 2018. "Intergenerational Wealth Mobility and the Role of Inheritance: Evidence from Multiple Generations.” The Economic Journal, 128(612): F482-F513.

Ager, Philipp. 2013. “The Persistence of de Facto Power: Elites and Economic Development in the US South, 1840-1960.” EHES Working Paper in Economics History No. 38.

Alston, Lee J. and Joseph P. Ferrie. 1999. Southern Paternalism and the American Welfare State: Economics, Politics, and Institutions in the South, 1865-1965. New York: Cambridge University Press.

Alvaredo, Facundo, Bertrand Garbinti, and Thomas Piketty. 2017. "On the Share of Inheritance in Aggregate Wealth: Europe and the USA, 1900-2010.” Economica 84(334): 239-260.

Atkinson, Anthony B., Thomas Piketty, and Emmanuel Saez. 2011. "Top Incomes in the Long Run of History.” Journal of Economic Literature, 49(1): 3-71.

Bailey, Martha, Connor Cole, Morgan Henderson, and Catherine Massey. 2017. "How Well Do Automated Methods Perform in Historical Samples? Evidence from New Ground Truth.” NBER Working Paper No. 24019.

Barro, Robert J. and Xavier Sala-i-Martin. 1992. Convergence. Journal of Political Economy, 100(2): 223-251.

Barth, Daniel, Nicholas W. Papageorge, and Kevin Thom. Forthcoming. "Genetic Endowments and Wealth Inequality.” Journal of Political Economy.

Becker, Gary S. and Nigel Tomes. 1986. "Human Capital and the Rise and Fall of Families.” Journal of Labor Economics, 4(3): S1-S39.

Becker, Gary S., Scott Duke Kominers, Kevin M. Murphy, and Jörg L. Spenkuch. 2018. “A Theory of Intergenerational Mobility.” Journal of Political Economy 126, no. S1: S7-S25.

Billings, Dwight B. 1982. "Class Origins of the 'New South': Planter Persistence and Industry in North Carolina.” American Journal of Sociology, 88: S52-S85. 
Black, Sandra E., and Paul J. Devereux. 2011. “Recent Developments in Intergenerational Mobility.” In Handbook of Labor Economics. Vol. 4, ed. Orley Ashenfelter and David Card, Chapter 16, 1487-1541. Elsevier.

Black, Sandra E., Paul J. Devereux, Petter Lundborg, and Kaveh Majlesi. Forthcoming. "Poor Little Rich Kids? The Determinants of the Intergenerational Transmission of Wealth.” Review of Economic Studies.

Blackmon, Douglas A. 2009. Slavery by Another Name: The Re-enslavement of Black Americans from the Civil War to World War II. New York: Anchor.

Bleakley, Hoyt, and Joseph Ferrie. 2016. "Shocking Behavior: Random Wealth in Antebellum Georgia and Human Capital Across Generations.” Quarterly Journal of Economics, 131(3): 1455-1495.

Bleakley, Hoyt and Sok Chul Hong. 2013. "When the Race between Education and Technology Goes Backwards: The Postbellum Decline of White School Attendance in the Southern US.” Working Paper.

Boserup, Simon, Wojciech Kopczuk, and Claus Kreiner. 2016. “The Role of Bequests in Shaping Wealth Inequality: Evidence from Danish Wealth Records.” American Economic Review, 106(5): 656-61.

Bowles, Samuel, and Herbert Gintis. 2002. "The Inheritance of Inequality.” Journal of Economic Perspectives, 16(3): 3-30.

Bryant, Jonathan M. 1996. How Curious a Land: Conflict and Change in Greene County, Georgia, 18501885. Chapel Hill: The University of North Carolina Press.

Calomiris, Charles W., and Jonathan Pritchett. 2016. "Betting on Secession: Quantifying Political Events Surrounding Slavery and the Civil War.” American Economic Review, 106(1): 1-23.

Caselli, Francesco, and Wilbur John Coleman II. 2001. The US structural transformation and regional convergence: A reinterpretation. Journal of Political Economy, 109(3): 584-616.

Charles, Kerwin Kofi, and Erik Hurst. 2003. “The Correlation of Wealth across Generations.” Journal of Political Economy, 111(6): 1155-1182.

Chetty, Raj, Nathaniel Hendren, Patrick Kline, and Emmanuel Saez. "Where is the Land of Opportunity? The Geography of Intergenerational Mobility in the United States." Quarterly Journal of Economics 129(4): 1553-1623.

Clark, Gregory. 2014. The Son Also Rises: Surnames and the History of Social Mobility. Princeton: Princeton University Press.

Cohen, William. 1991. At Freedom's Edge: Black Mobility and the Southern White Quest for Racial Control, 1861-1915. Baton Rouge: Louisiana State University Press.

Collins, William J., and Ariell Zimran. 2018. “The Economic Assimilation of Irish Famine Migrants to the United States.” NBER Working Paper No. 25287.

Dupont, Brandon, and Joshua L. Rosenbloom. 2018. "The Economic Origins of the Postwar Southern Elite.” Explorations in Economic History, 68: 119-131. 
Eli, Shari, Laura Salisbury, and Allison Shertzer. 2018. Ideology and Migration after the American Civil War. The Journal of Economic History, 78(3), pp.822-861.

Engerman, Stanley L. 1966. “The Economics Impact of the Civil War.” Explorations in Economic History, 3(3): 176-200.

Engerman, Stanley L. 2000. "Slavery and its Consequences for the South in the Nineteenth Century." The Cambridge Economic History of the United States, 329-366.

Engerman, Stanley and Kenneth L. Sokoloff. 1997. "Factor Endowments, Institutions, and Differential Paths of Growth among New World Economies.” How Latin America Fell Behind, 260-304.

Engerman, Stanley L., and Kenneth L. Sokoloff. 2002. "Factor Endowments, Inequality, and Paths of Development among New World Economies.” NBER Working Paper No. 9259.

Fagereng, Andreas, Magne Mogstad, and Marte Rønning. 2018. "Why Do Wealthy Parents Have Wealthy Children?” CESifo Working Paper No. 6955.

Feigenbaum, James J., James Lee, and Filippo Mezzanotti. 2018. “Capital Destruction and Economic Growth: The Effects of Sherman’s March, 1850-1920.” NBER Working Paper No. 25392.

Ferrie, Joseph P. 1996. “A New Sample of Males Linked from the Public Use Microdata Sample of the 1850 U.S. Federal Census of Population to the 1860 U.S. Federal Census Manuscript Schedules.” Historical Methods, 29(4): 141-156.

Fladeland, Betty L. 1976. “Compensated Emancipation: A Rejected Alternative.” The Journal of Southern History, 42(2): 169-186.

Fogel, Robert W., and Stanley L. Engerman. 1974. Time on the Cross: The Economics of American Negro Slavery. Columbus: Little, Brown and Company.

Fogel, Robert W., and Stanley L. Engerman. 1977. "Explaining the Relative Efficiency of Slave Agriculture in the Antebellum South.” The American Economic Review, 67(3): 275-296.

Foner, Eric. 1982. “Reconstruction Revisited.” Reviews in American History, 10(4): 82-100.

Foner, Eric. 1988. Reconstruction: America’s Unfinished Revolution, 1863-1877. New York: Harper and Row.

Goldin, Claudia. 1973. “The Economics of Emancipation.” Journal of Economic History, 33(1): 6685.

Goldin, Claudia, and Lawrence F. Katz. 2008. The Race between Education and Technology. Cambridge, MA: Harvard University Press.

González, Felipe, Guillermo Marshall, and Suresh Naidu. 2017. "Start-up Nation? Slave Wealth and Entrepreneurship in Civil War Maryland.” Journal of Economic History, 77(2): 373-405.

Haines, Michael R. 2010. Historical, Demographic, Economic, and Social Data: The United States, 17902002. Ann Arbor, MI: Inter-university Consortium for Political and Social Research [distributor], 201005-21. https://doi.org/10.3886/ICPSR02896.v3

Hall, Andrew, Connor Huff, and Shiro Kuriwaki. Forthcoming. "Wealth, Slave Ownership, and Fighting 
for the Confederacy: An Empirical Study of the American Civil War.” American Political Science Review.

Higgs, Robert. 1973. "Race, Tenure, and Resource Allocation in Southern Agriculture, 1910.” Journal of Economic History, 33(1): 149-169.

Higgs, Robert. 1977. Competition and Coercion: Blacks in the American Economy 1865-1914. New York: Cambridge University Press.

Kearl, James R., and Clayne L. Pope. 1986. "Unobservable Family and Individual Contributions to the Distributions of Income and Wealth.” Journal of Labor Economics, 4(3): S48-S79.

Kilbourne, Jr., Richard H. 1995. Debt, Investment, Slaves: Credit Relations in East Feliciana Parish, Louisiana, 1825-1885. Tuscaloosa: The University of Alabama Press.

Kuhn, Moritz, Moritz Schularick, and Ulrike I. Steins. 2017. "Income and Wealth Inequality in America, 1949-2016.” Federal Reserve Bank of Minneapolis.

Logan, Trevon D. 2018. “Do Black Politicians Matter?” NBER Working Paper No. 24190.

Martin, Bonnie. 2010. “Slavery’s Invisible Engine: Mortgaging Human Property.” Journal of Southern History, 76(4): 817-866.

Martin, Fernando M. 2017. “A Short History of Prices, Inflation Since the Founding of the U.S.” The Regional Economist. Federal Reserve Bank of St. Louis, Second Quarter.

Martins, Igor, Jeanne Cilliers, and Johan Fourie. 2019. "Expropriation with Partial Compensation: Slaveholder Reparations and Intergenerational Outcomes.” Working Paper.

Metzer, Jacob. 1975. "Rational Management, Mosdern Business Practices, and Economies of Scale in the Ante-Bellum Southern Plantations.” Explorations in Economic History, 12(2): 123-150.

Miller, Melinda C. Forthcoming. “'The Righteous and Reasonable Ambition to Become a Landholder’: Land and Racial Inequality in the Postbellum South.” Review of Economics and Statistics.

Mitchell, B., The Rise of the Cotton Mills in the South (Baltimore, 1921).

Naidu, Suresh. 2010. "Recruitment Restrictions and Labor Markets: Evidence from the Postbellum U.S. South.” Journal of Labor Economics, 28(2): 413-445.

Oakes, James. 2012. Freedom National: The Destruction of Slavery in the United States, 1861-1865. WW Norton \& Company.

Olivetti, Claudia, and M. Daniele Paserman. 2015. "In the Name of the Son (and the Daughter): Intergenerational Mobility in the United States, 1850-1940.” American Economic Review, 105(8): 2695-2724.

Olmstead, Alan L., and Paul W. Rhode. 2008. "Biological Innovation and Productivity Growth in the Antebellum Cotton Economy.” Journal of Economic History, 68(04): 1123-1171.

Oubre, Claude F. 1978. Forty Acres and a Mule: The Freedmen's Bureau and Black Land Ownership. Baton Rouge: Louisiana State University Press.

Pfeffer, Fabian T., and Alexandra Killewald. 2018. "Generations of Advantage: Multigenerational Correlations in Family Wealth.” Social Forces, 96(4): 1411-1442. 
Piketty, Thomas. 2014. Capital in the Twenty-First Century. Harvard University Press

Ransom, Roger. 2005. "Reconstructing Reconstruction: Options and Limitations to Federal Policies on Land Distribution in 1866-67.” Civil War History, 51(4): 364-377.

Ransom, Roger, and Richard Sutch. 1975. "The Impact of the Civil War and of Emancipation on Southern Agriculture.” Explorations in Economic History, 12(1): 1-28.

Ransom, Roger, and Richard Sutch. 1977. One Kind of Freedom: The Economic Consequences of Emancipation. New York: Cambridge University Press.

Reid, Joseph D. 1973. "Sharecropping As An Understandable Market Response: The Post-Bellum South.” The Journal of Economic History, 33(1): 106-130.

Salisbury, Laura. 2017. Women's income and marriage markets in the United States: Evidence from the Civil War pension. The Journal of Economic History, 77(1), pp.1-38.

Scheidel, Walter. 2017. The Great Leveler: Violence and the History of Inequality from the Stone Age to the Twenty-First Century. Princeton University Press.

Shlomowitz, Ralph. 1979. "The origins of Southern sharecropping.” Agricultural History, 53(3): 557575.

Soltow, Lee. 1975. Men and Wealth in the United States, 1850-1870. New Haven: Yale University Press.

Steckel, Richard H. 1994. "Census Manuscript Schedules Matched with Property Tax Lists: A Source of Information on Long-Term Trends in Wealth Inequality.” Historical Methods, 27(2): 71-85.

Toman, Jane T. 2005. “The Gang System and Comparative Advantage.” Explorations in Economic History, 42(2): 310-323.

Wiener, Jonathan M. 1975. "Planter-Merchant Conflict in Reconstruction Alabama.” Past \& Present, 68: 73-94.

Wiener, Jonathan M. 1978. Social Origins of the New South: Alabama, 1860-1885. Baton Rouge: Louisiana State University Press.

Williamson, Samuel H. and Louis Cain. 2019. “Measuring Slavery in 2016 Dollars,” MeasuringWorth, 2019. URL: www.measuringworth.com/slavery.php

Woodman, Harold D. 1977. "Sequel to Slavery: The New History Views the Postbellum South.” Journal of Southern History, 43(4): 523-554.

Woodward, C. Vann. 1951. Origins of the New South. Baton Rouge: Louisiana State University Press.

Wright, Gavin. 1974. “Cotton Competition and the Post-bellum Recovery of the American South.” Journal of Economic History, 34(3): 610-635.

Wright, Gavin. 1978. The Political Economy of the Cotton South: Households, Markets, and Wealth in the Nineteenth Century. New York: W. W. Norton.

Wright, Gavin. 1986. Old South, New South: Revolutions in the Southern Economy Since the Civil War. New York: Basic Books. 


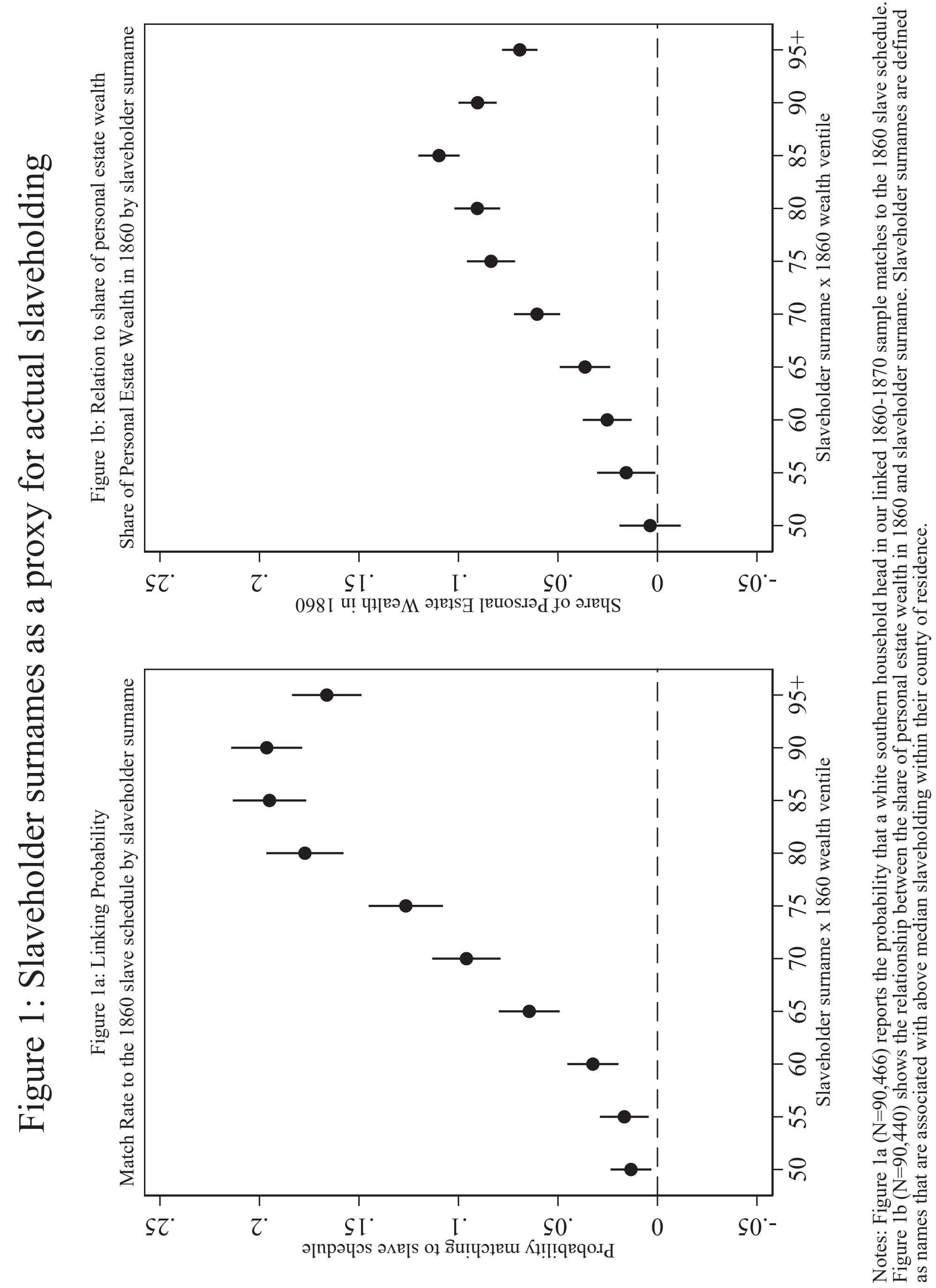




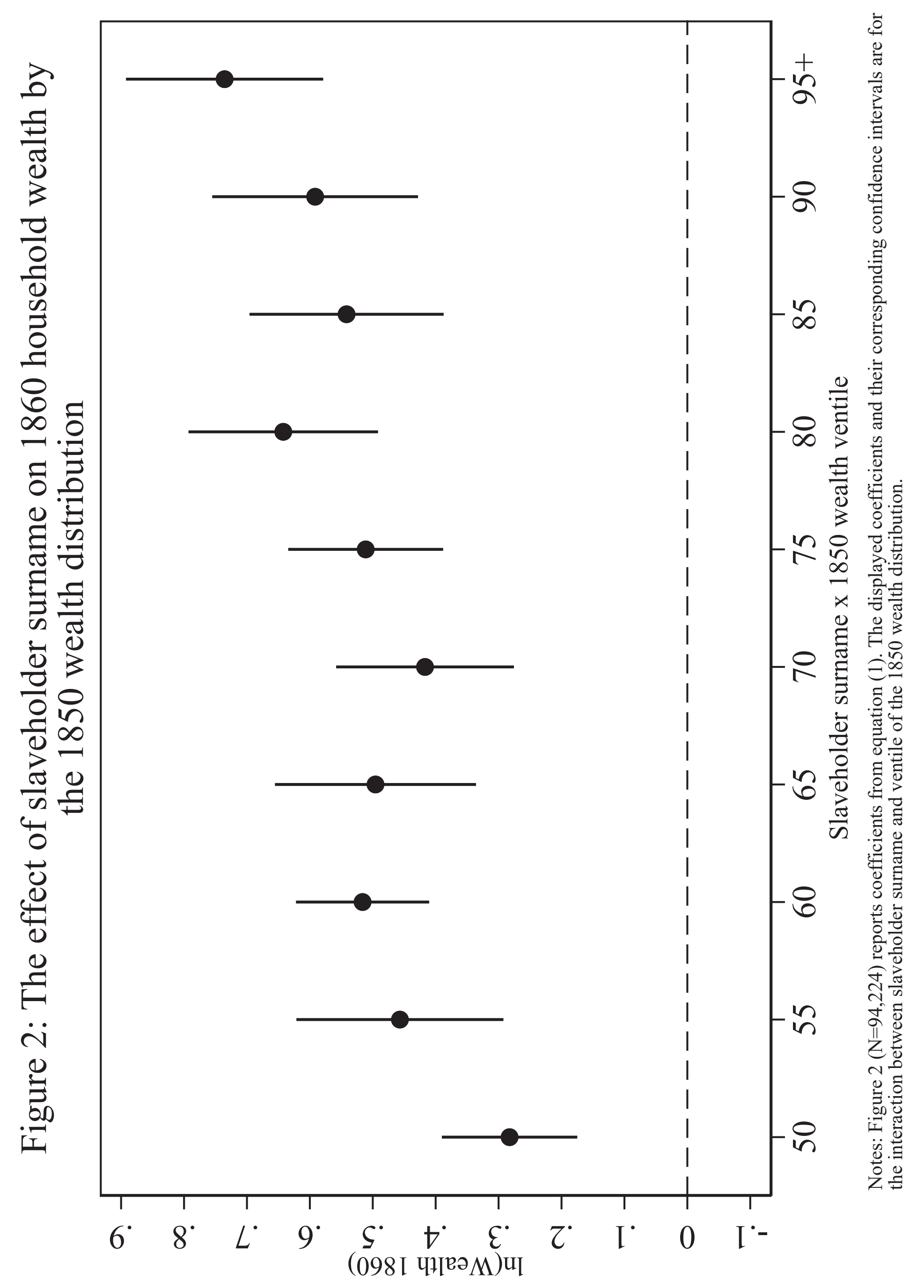




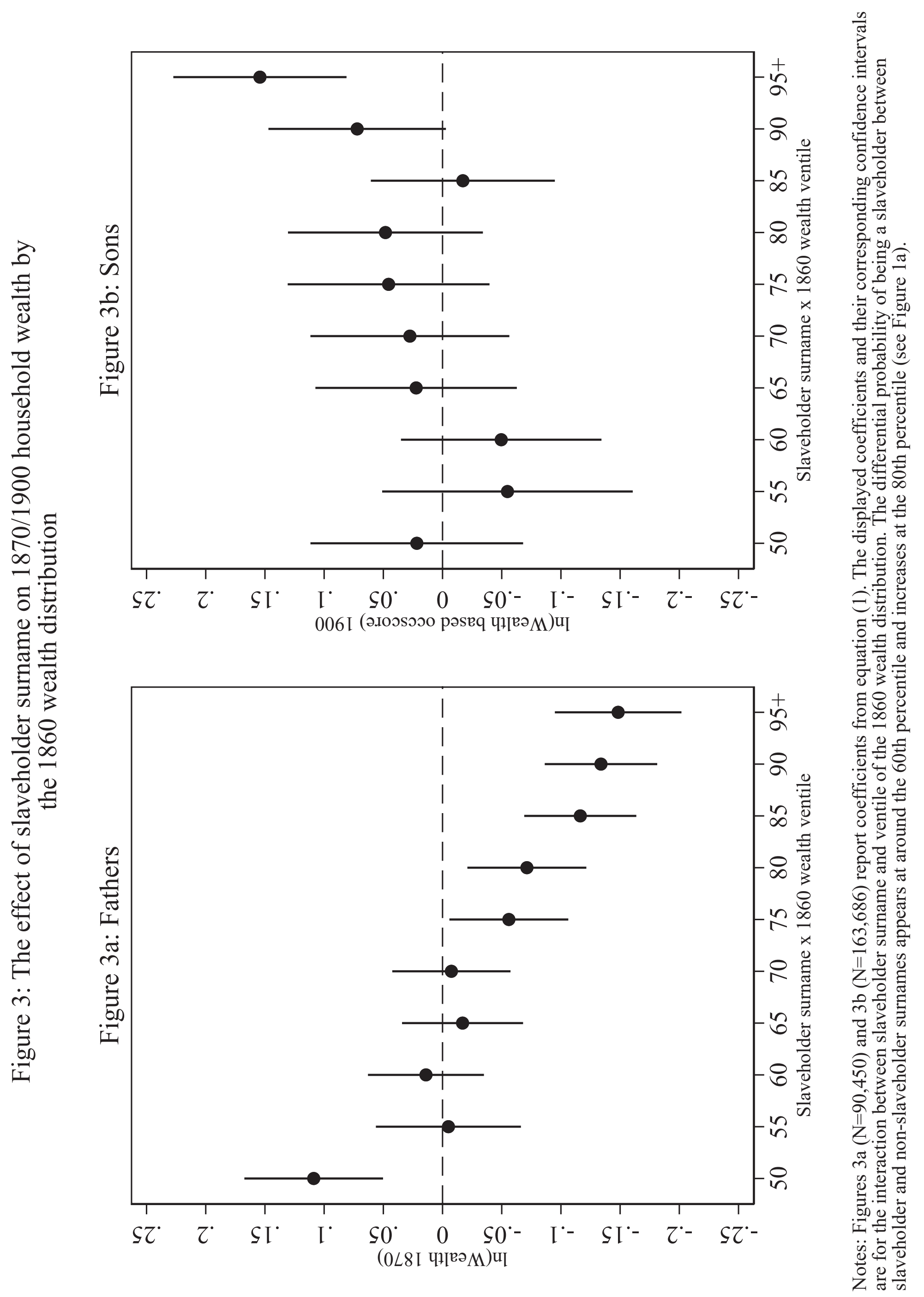




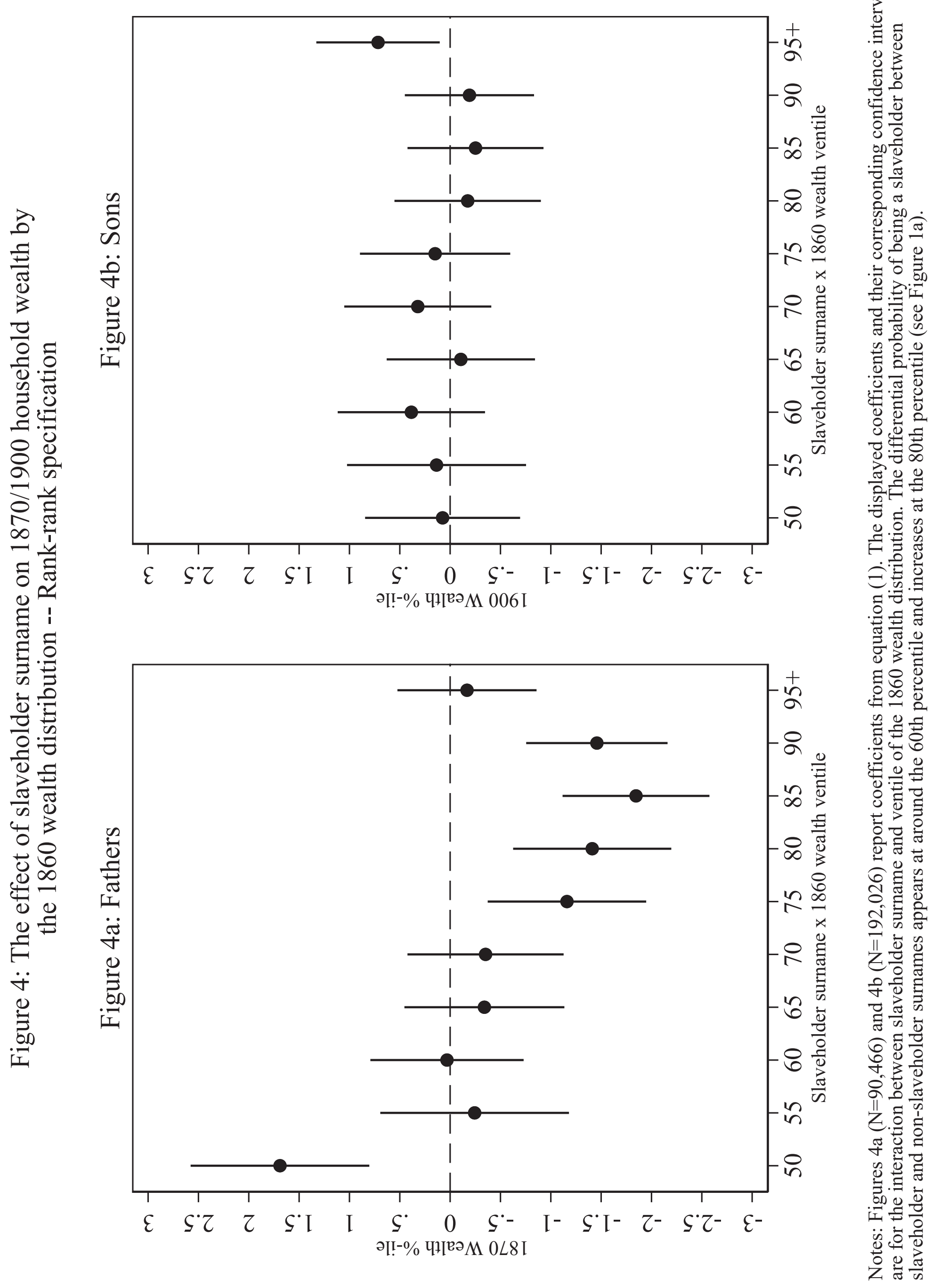




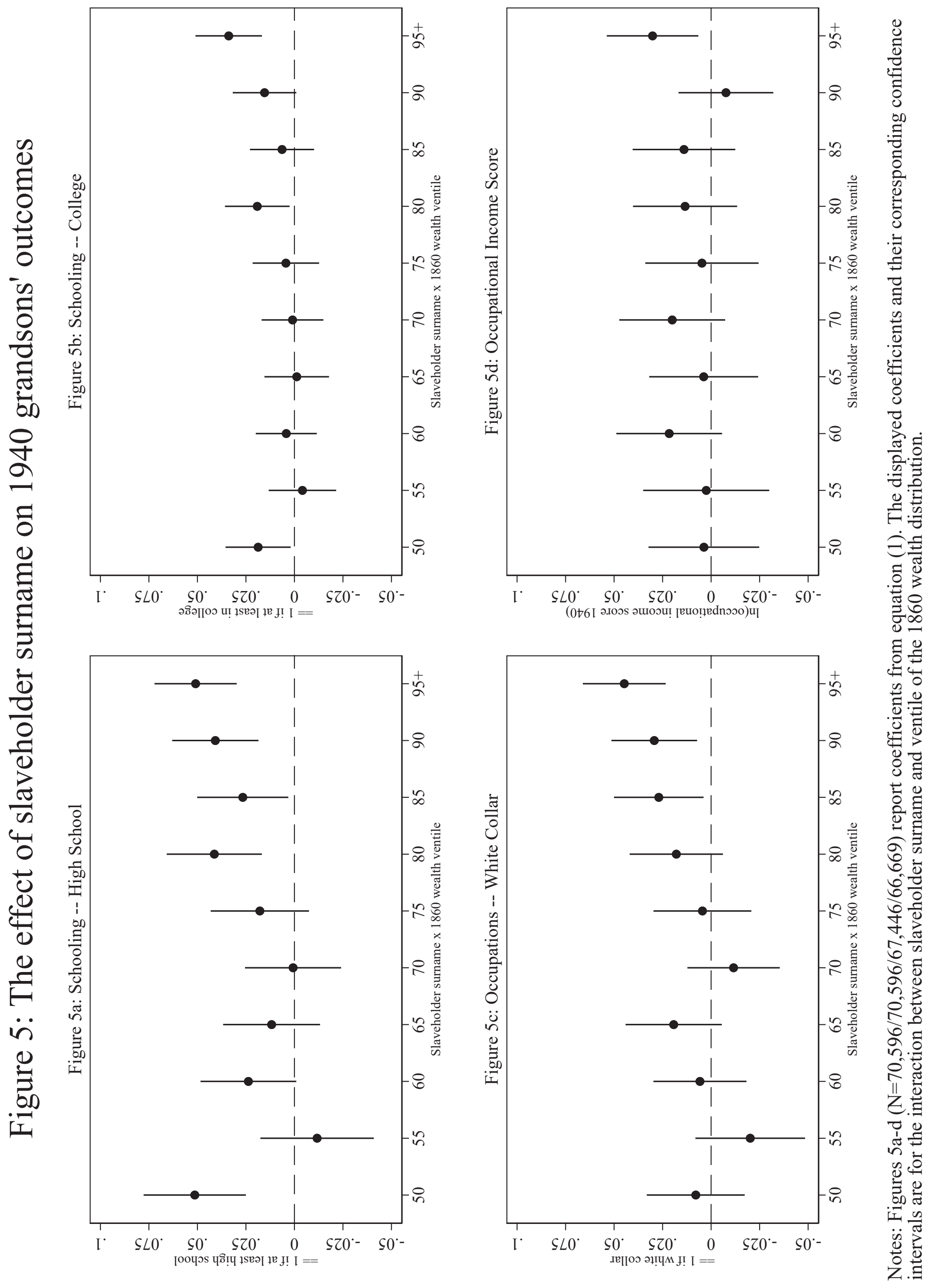




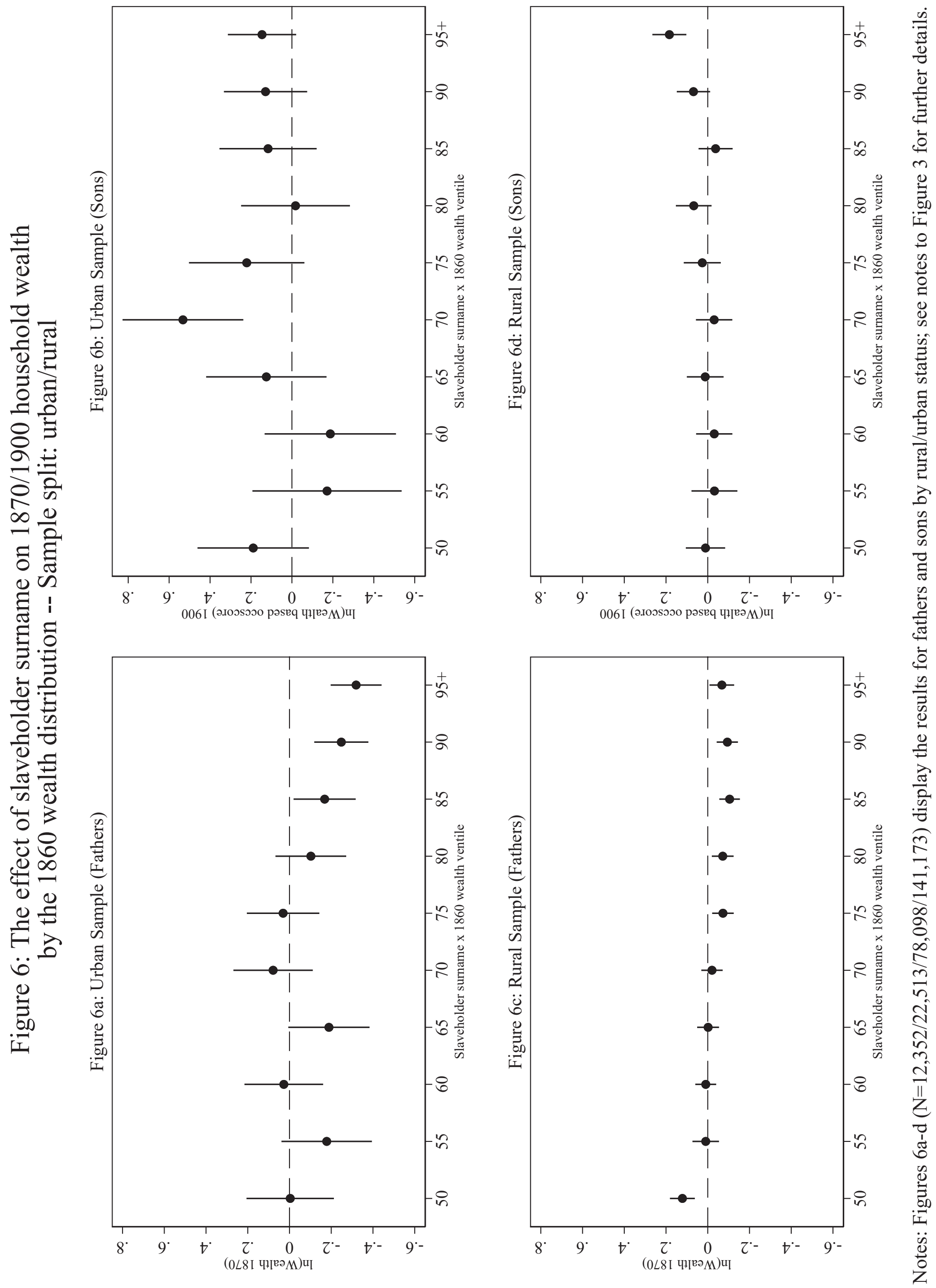



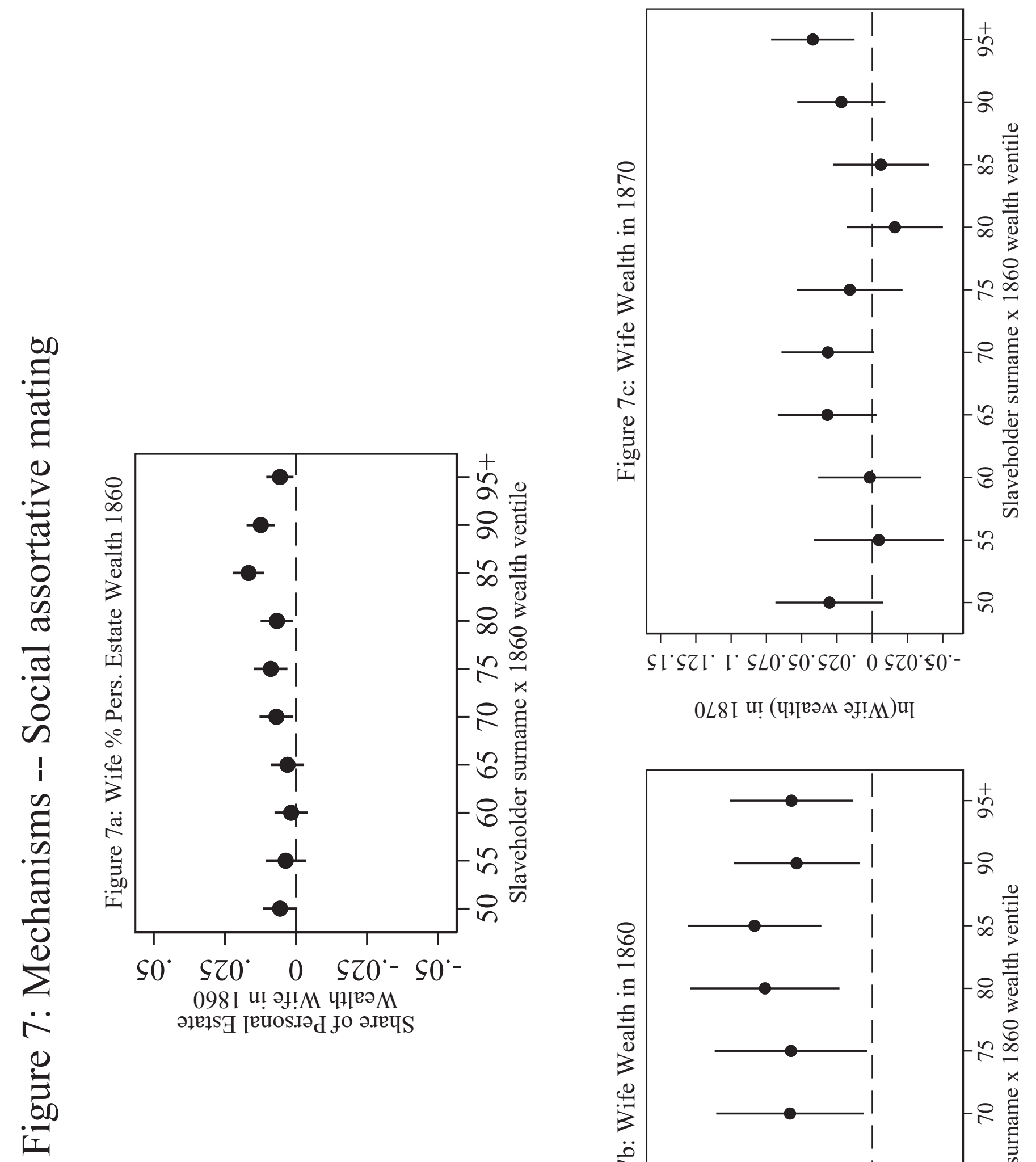

过

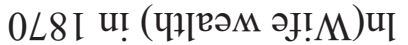

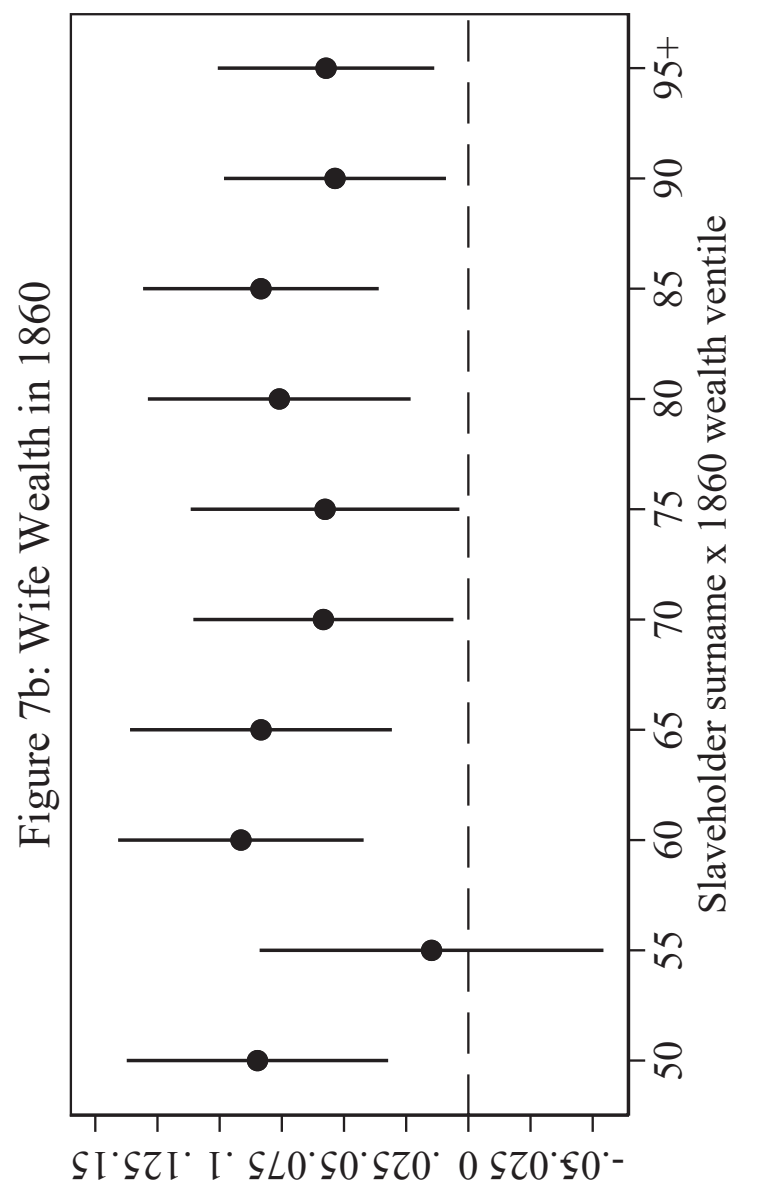

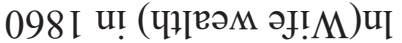




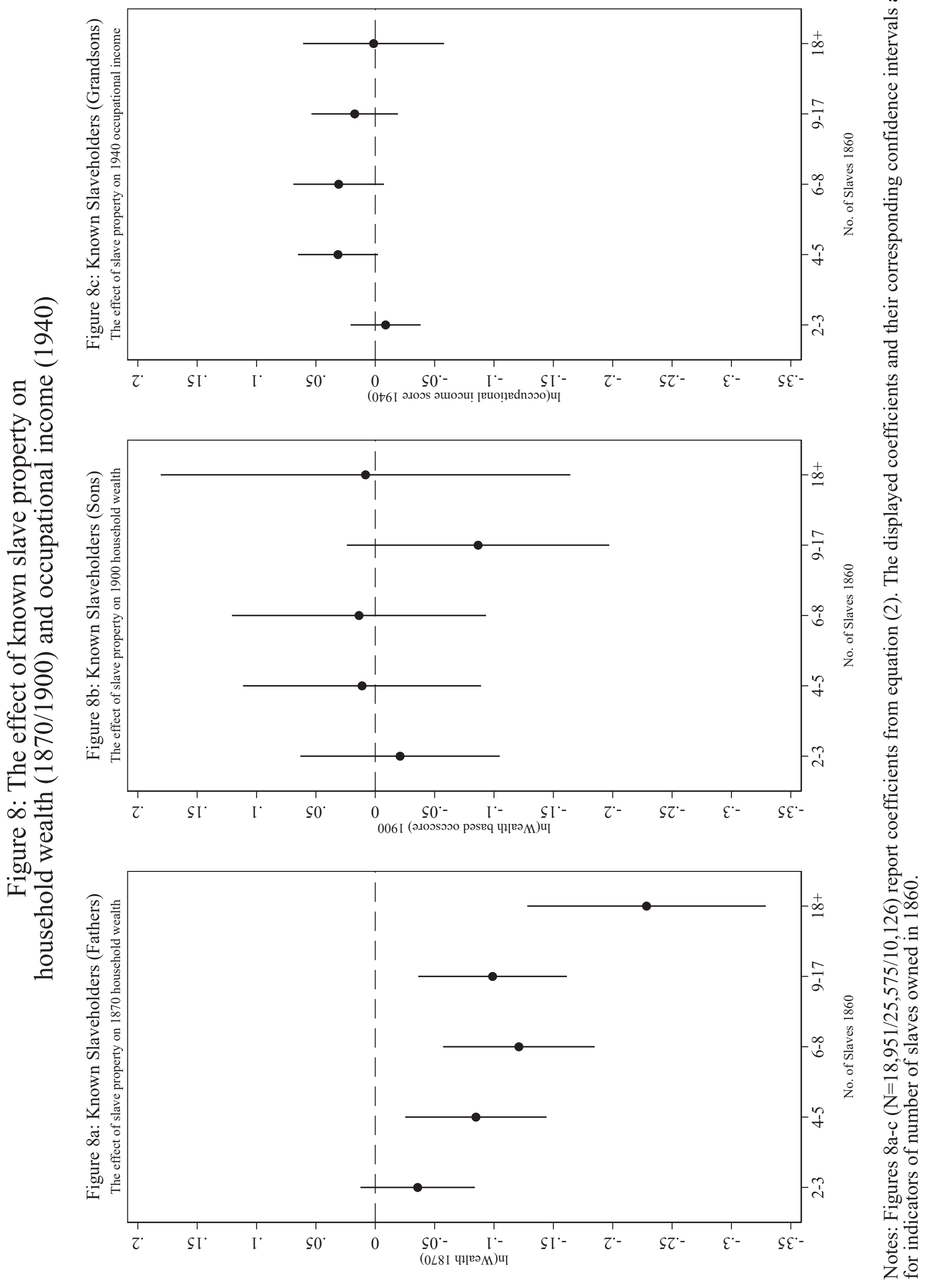




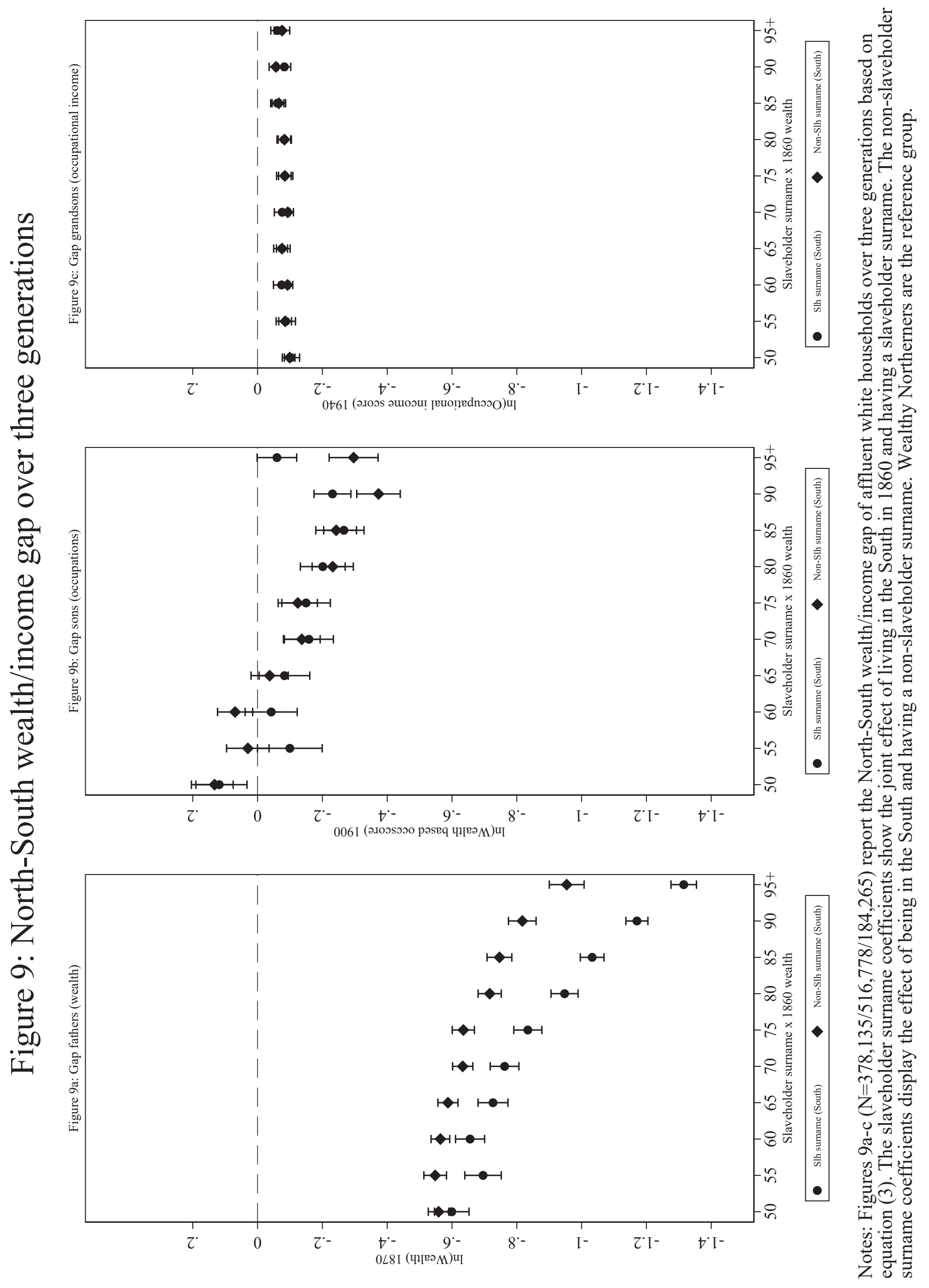




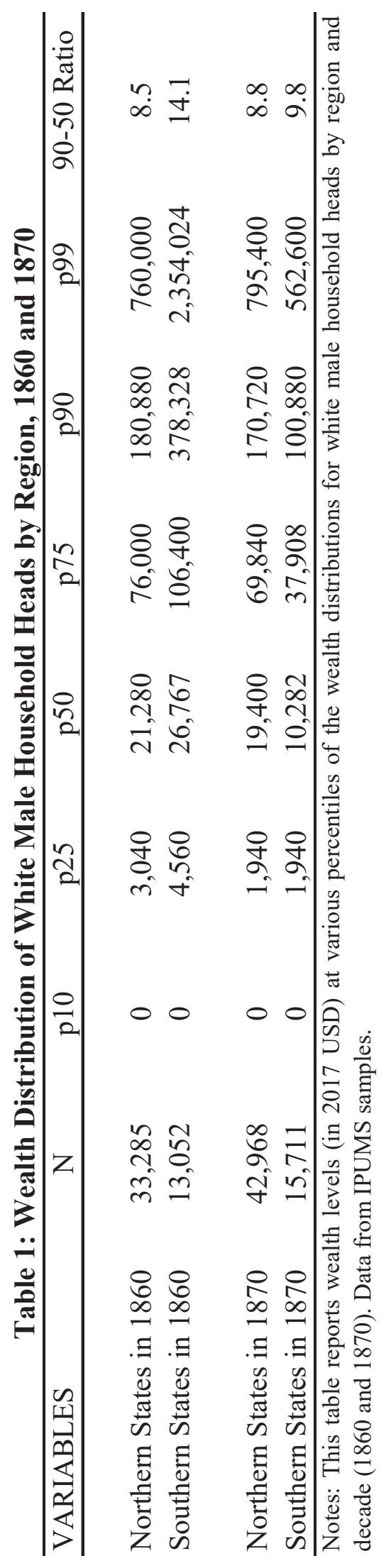


The intergenerational effects of a large wealth shock: White Southerners after the Civil War

\author{
Philipp Ager \\ University of Southern \\ Denmark and CEPR
}

\author{
Leah Boustan \\ Princeton and NBER
}

Katherine Eriksson

UC-Davis and NBER

September 2019

Appendix material: For Online Publication Only 


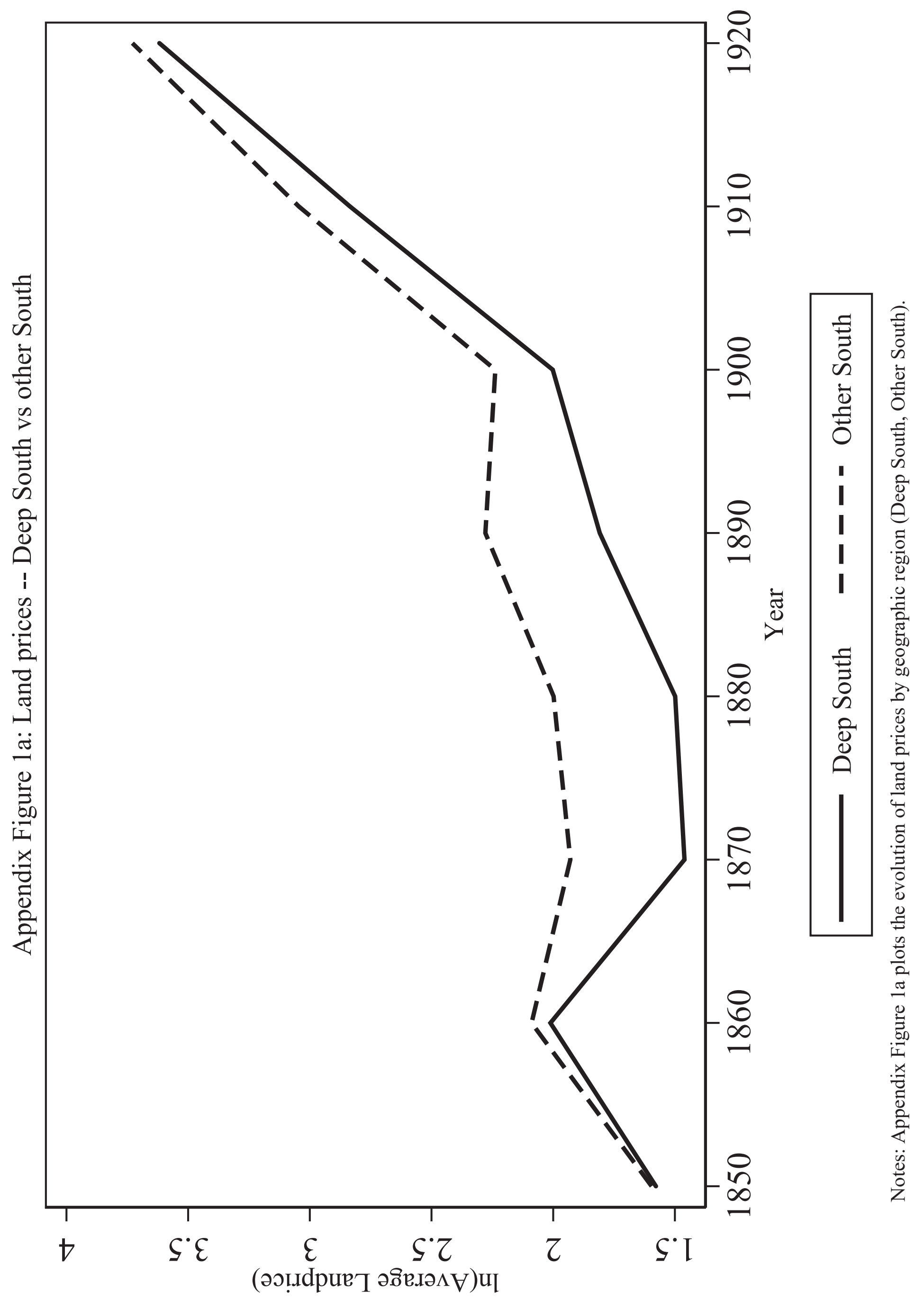




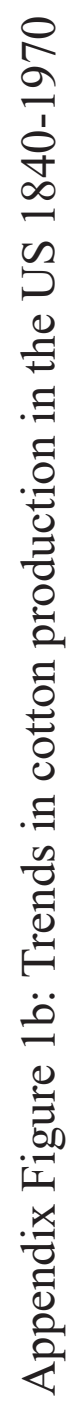

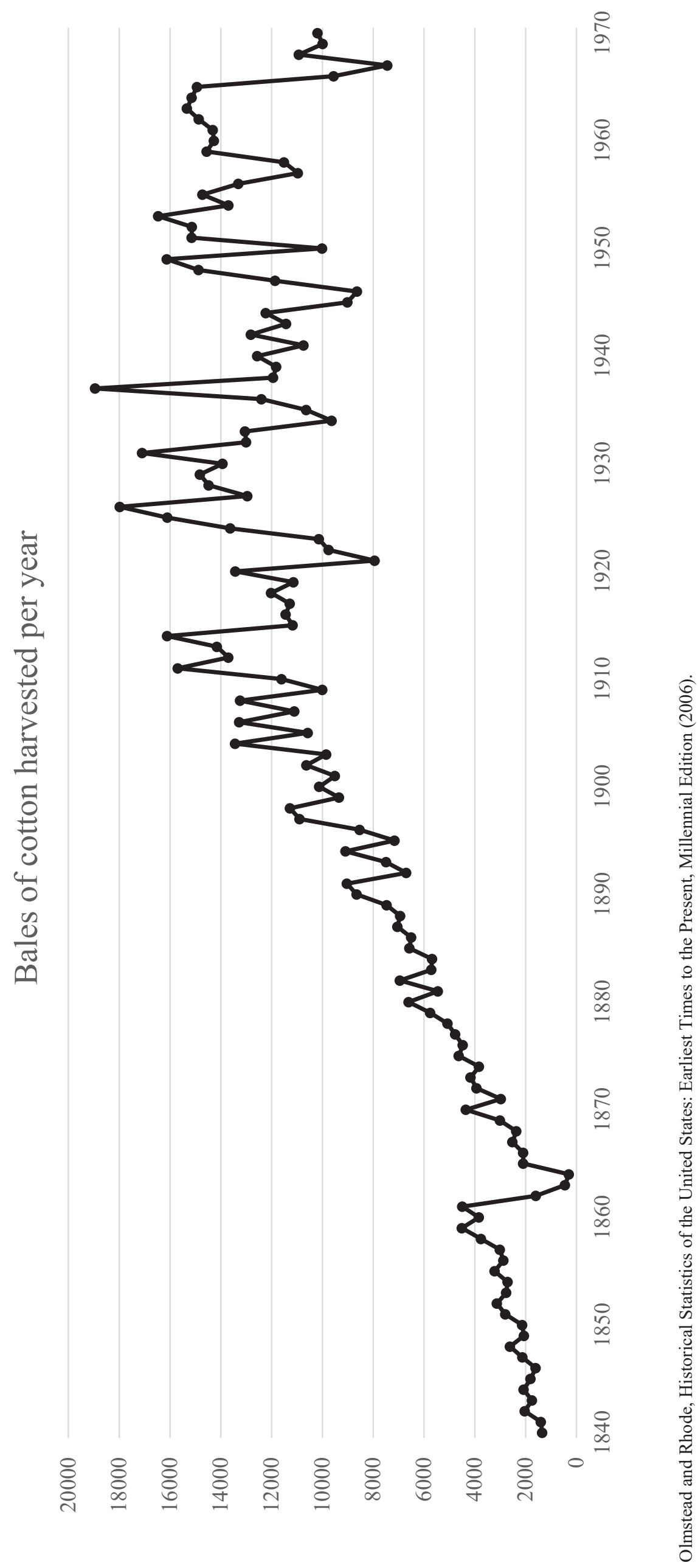




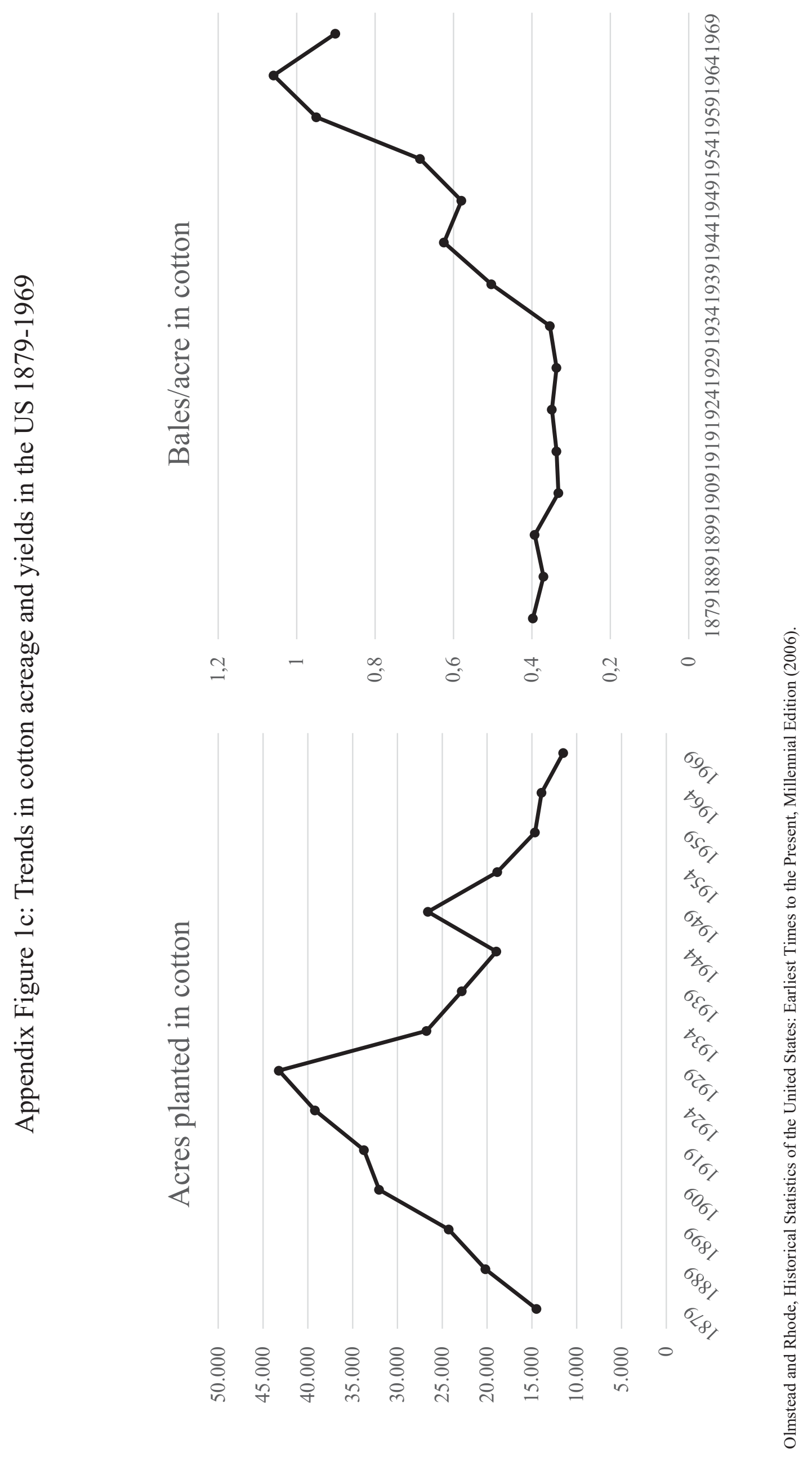




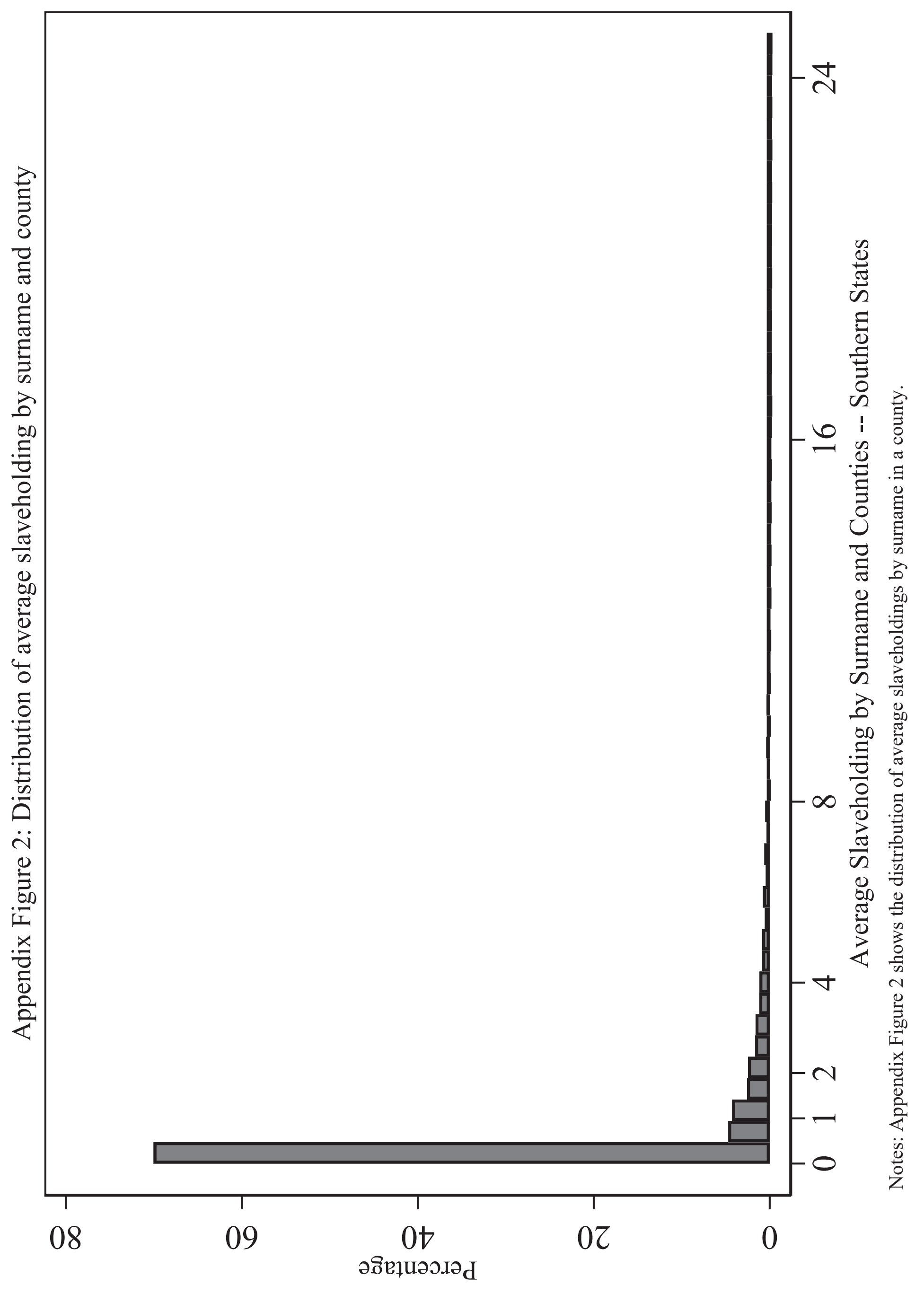




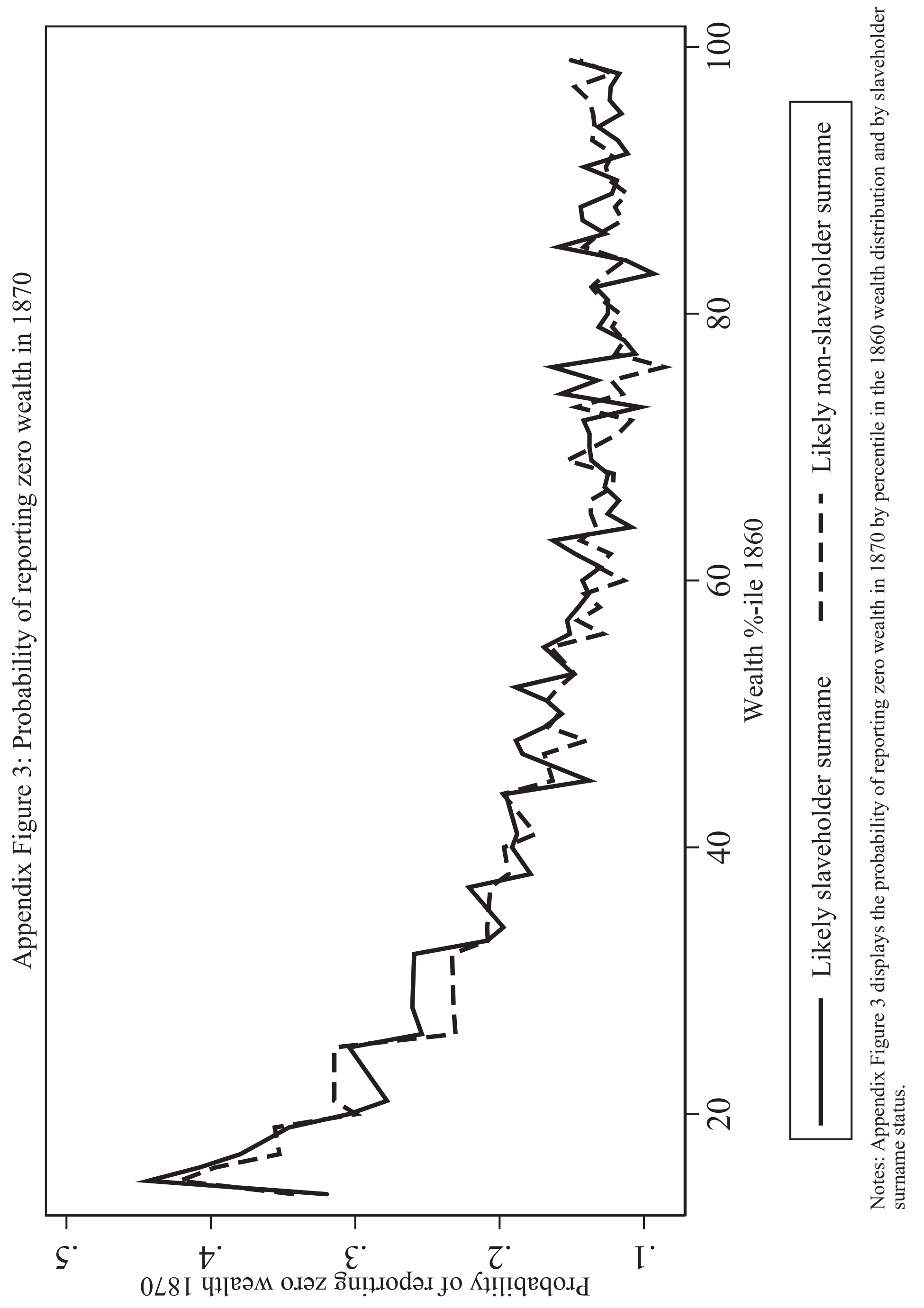




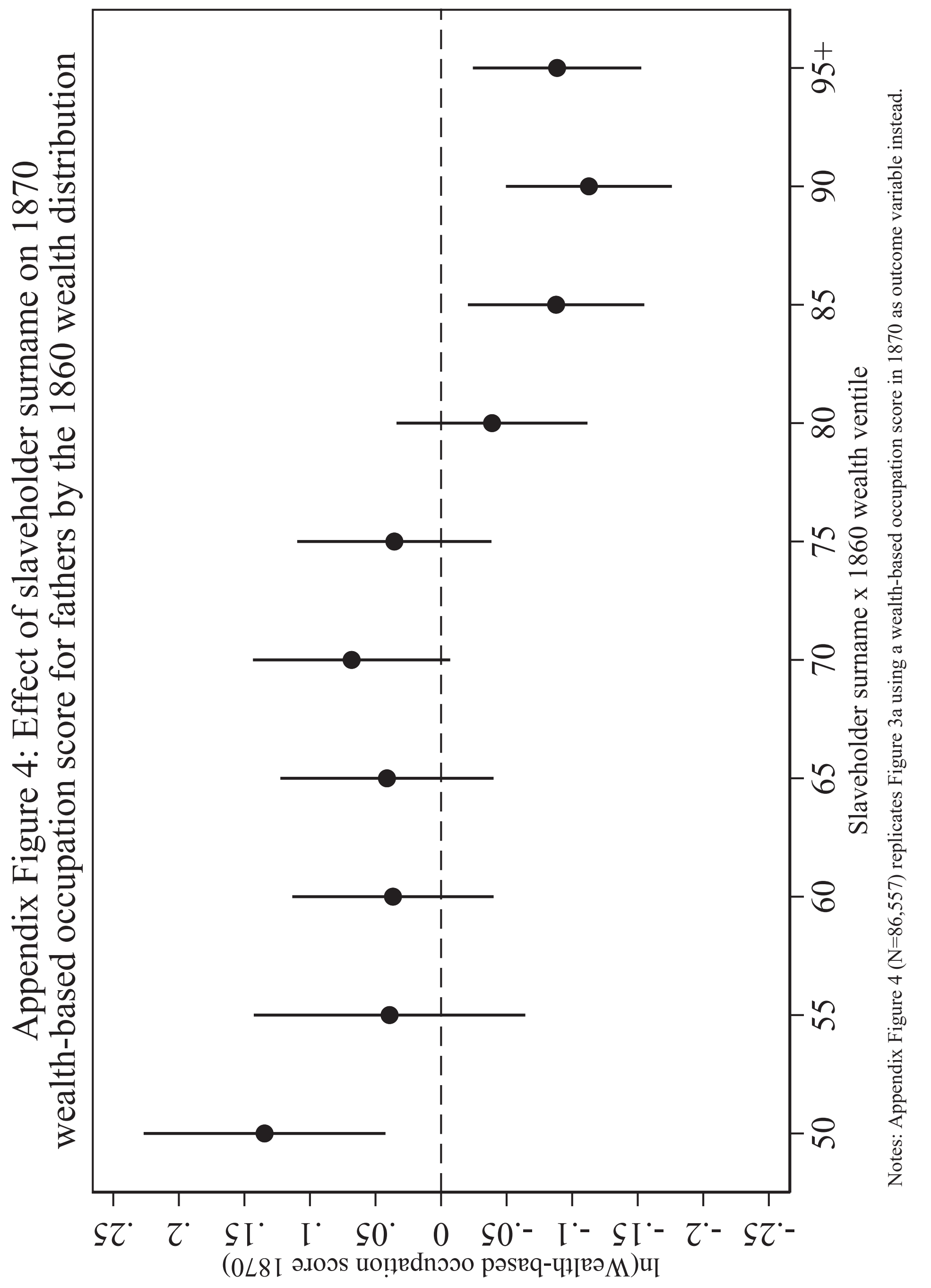




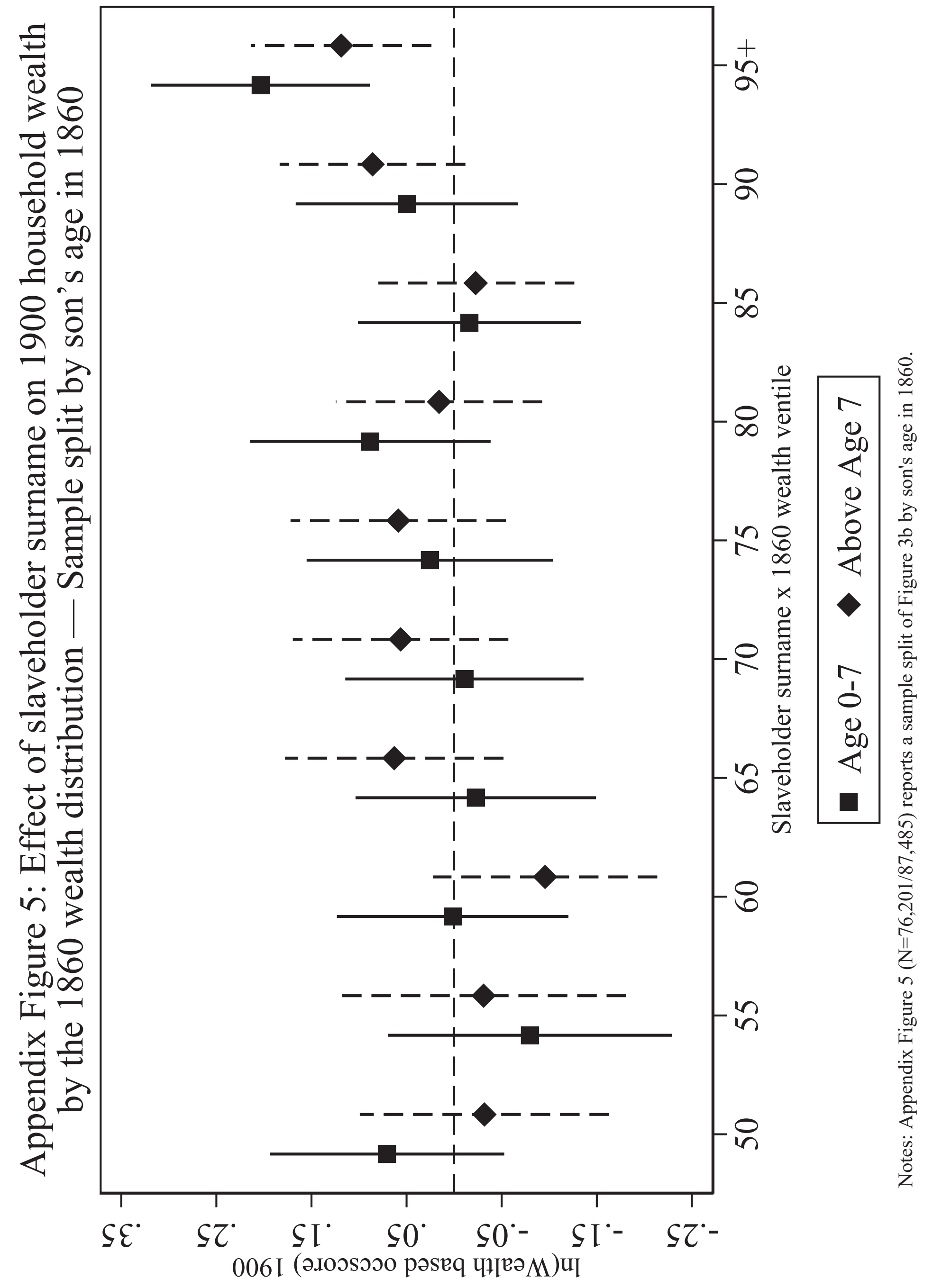




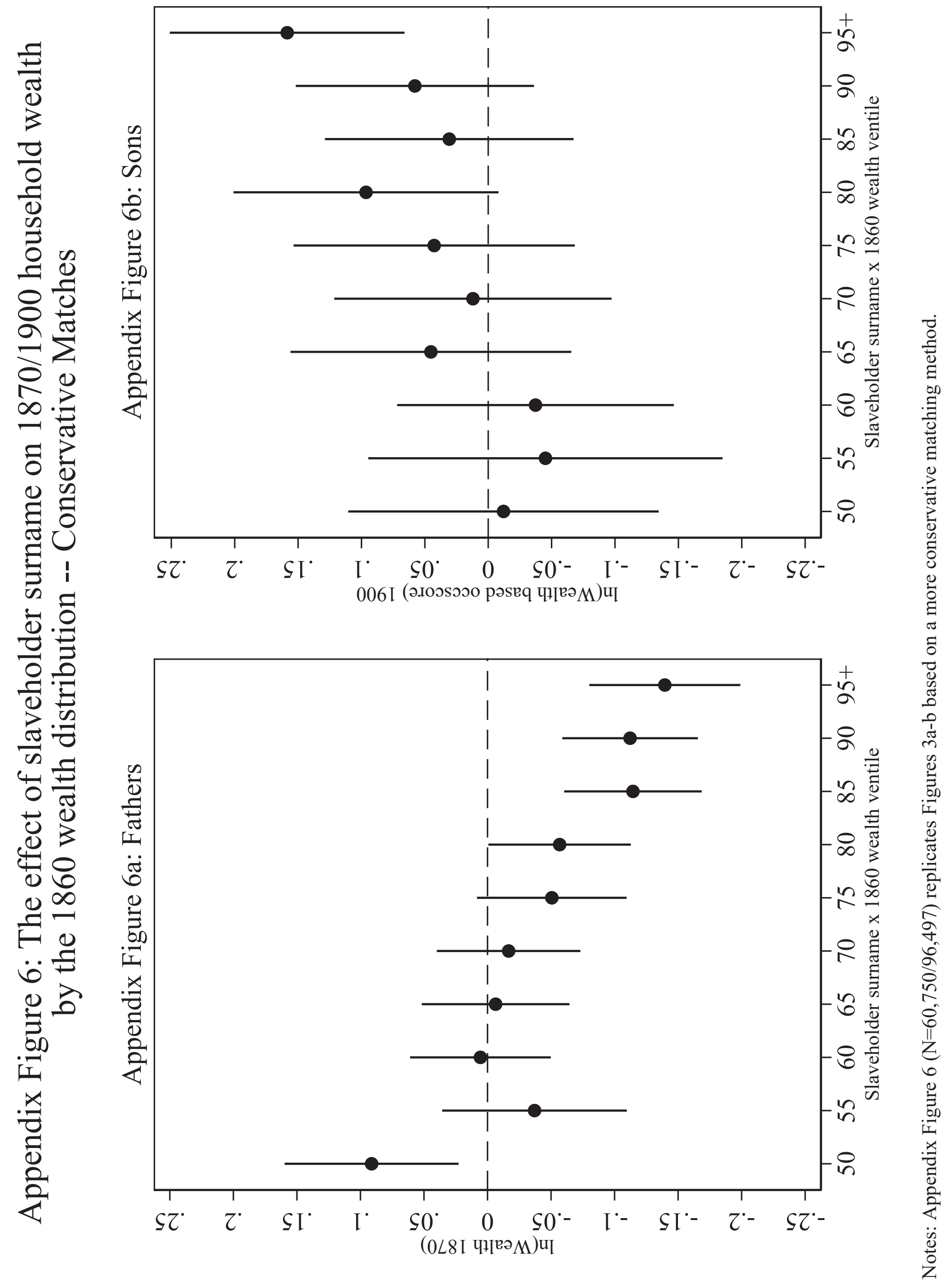




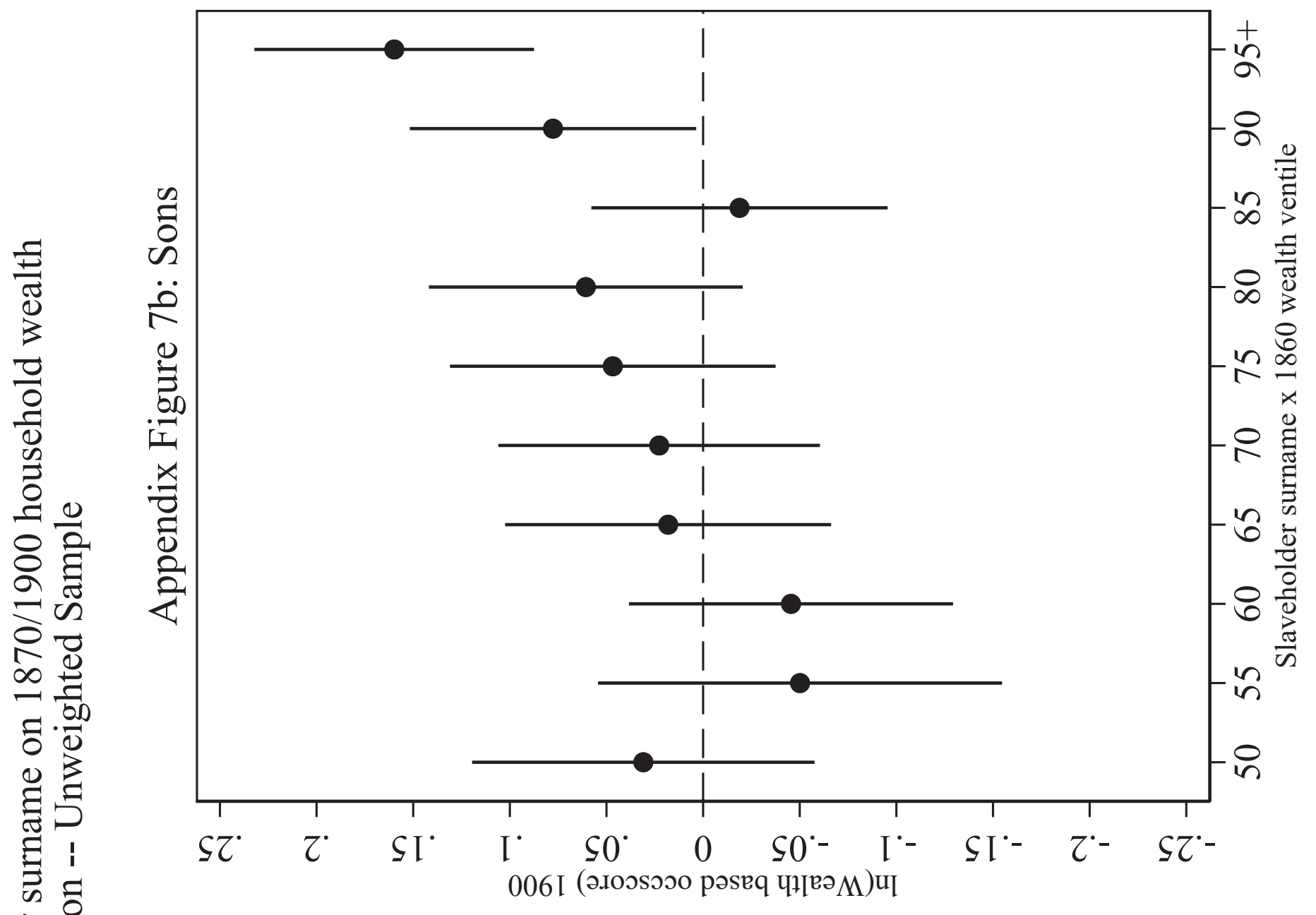

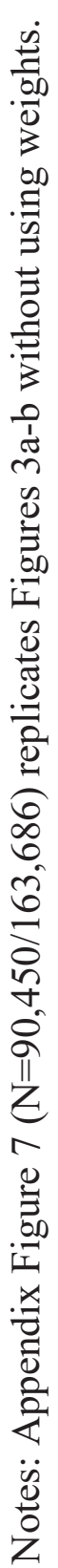




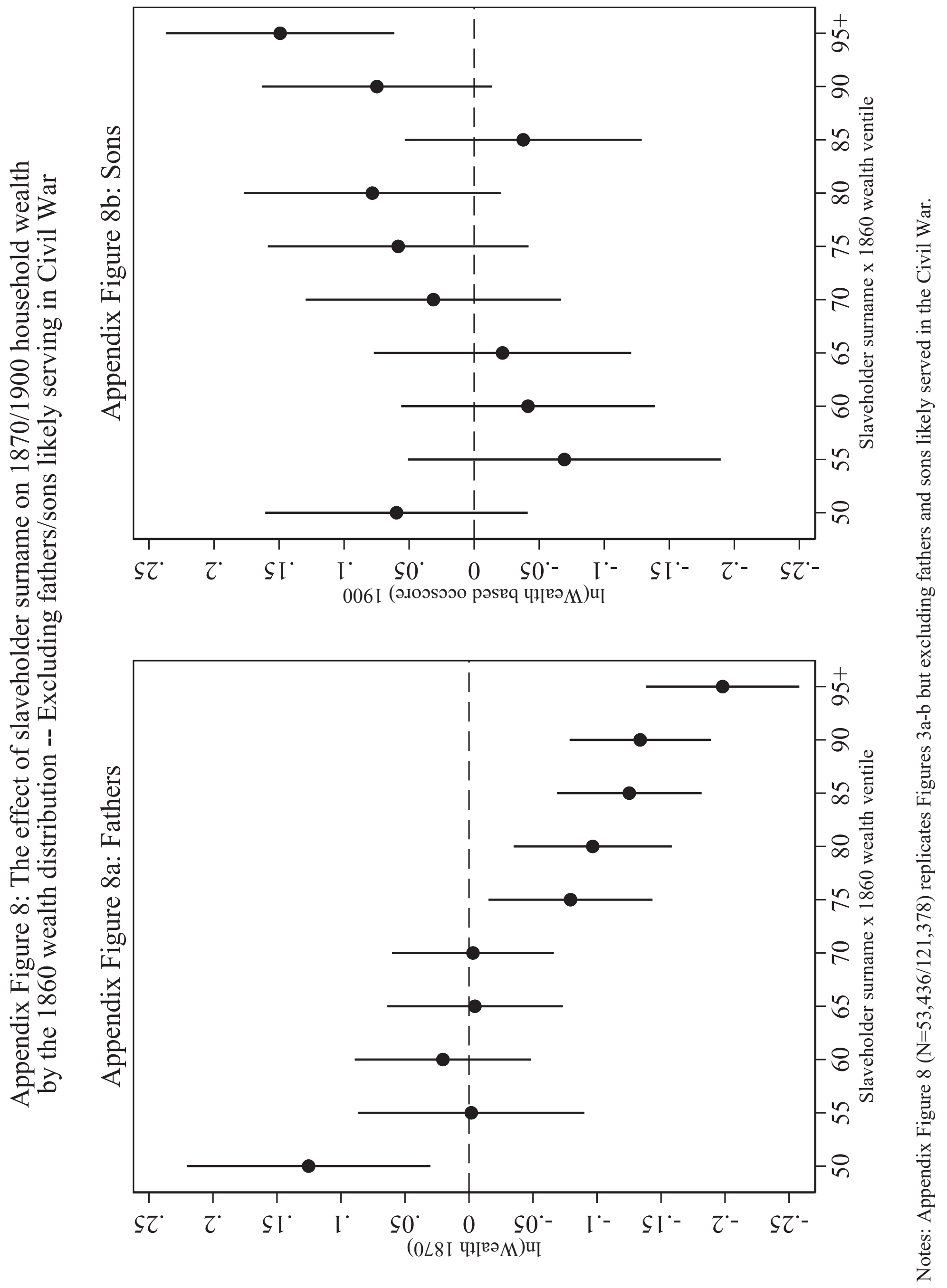




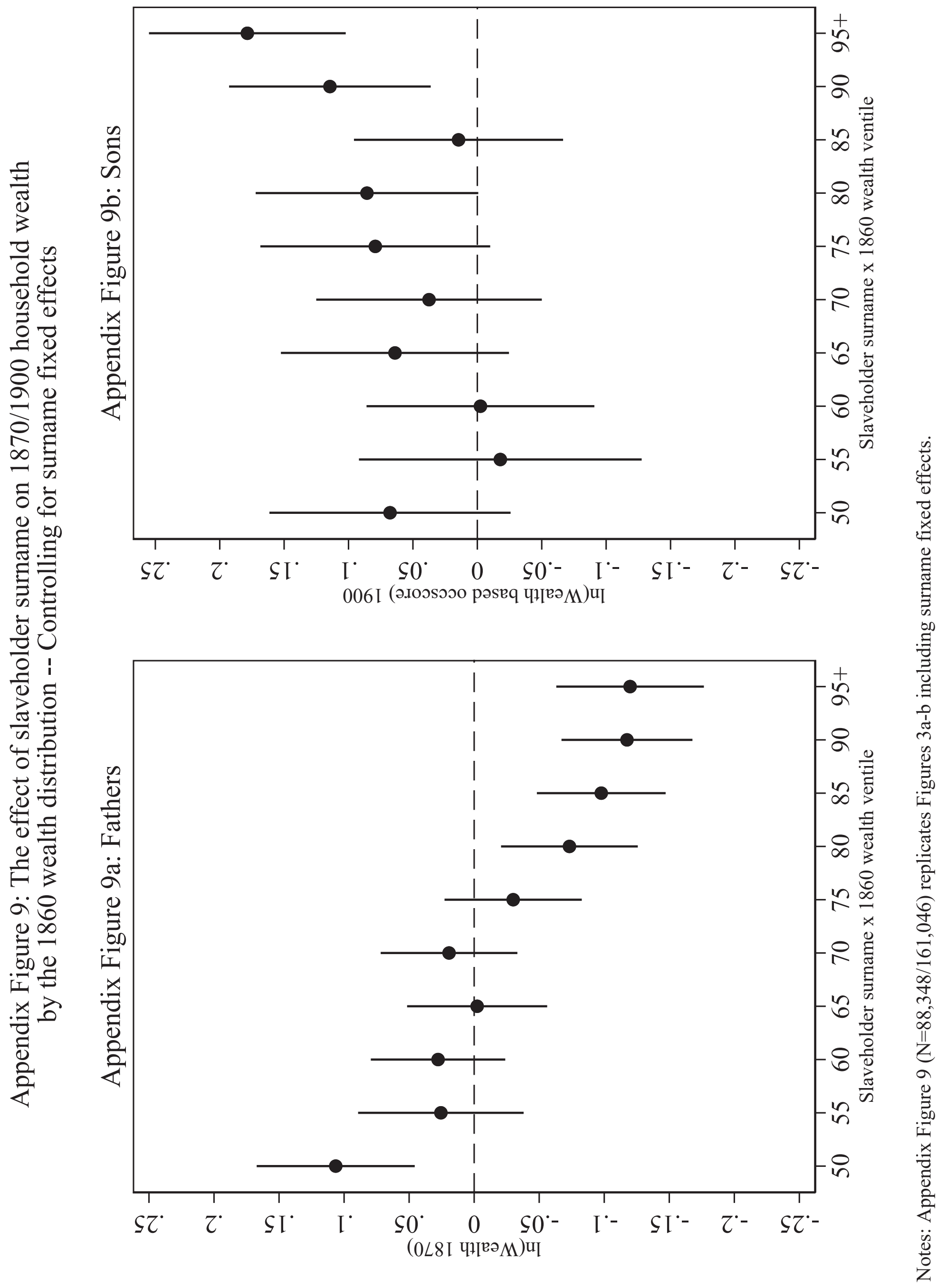




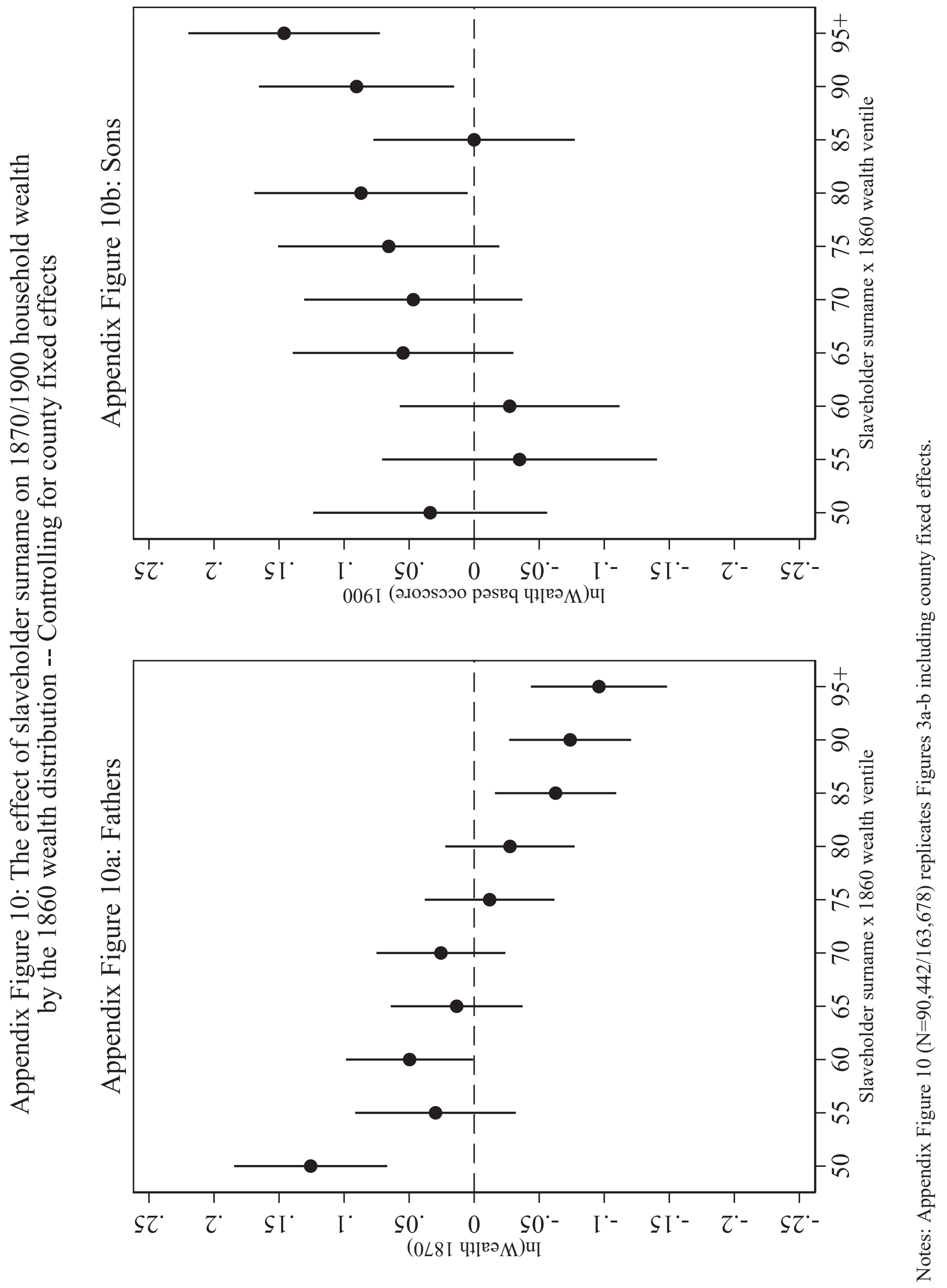




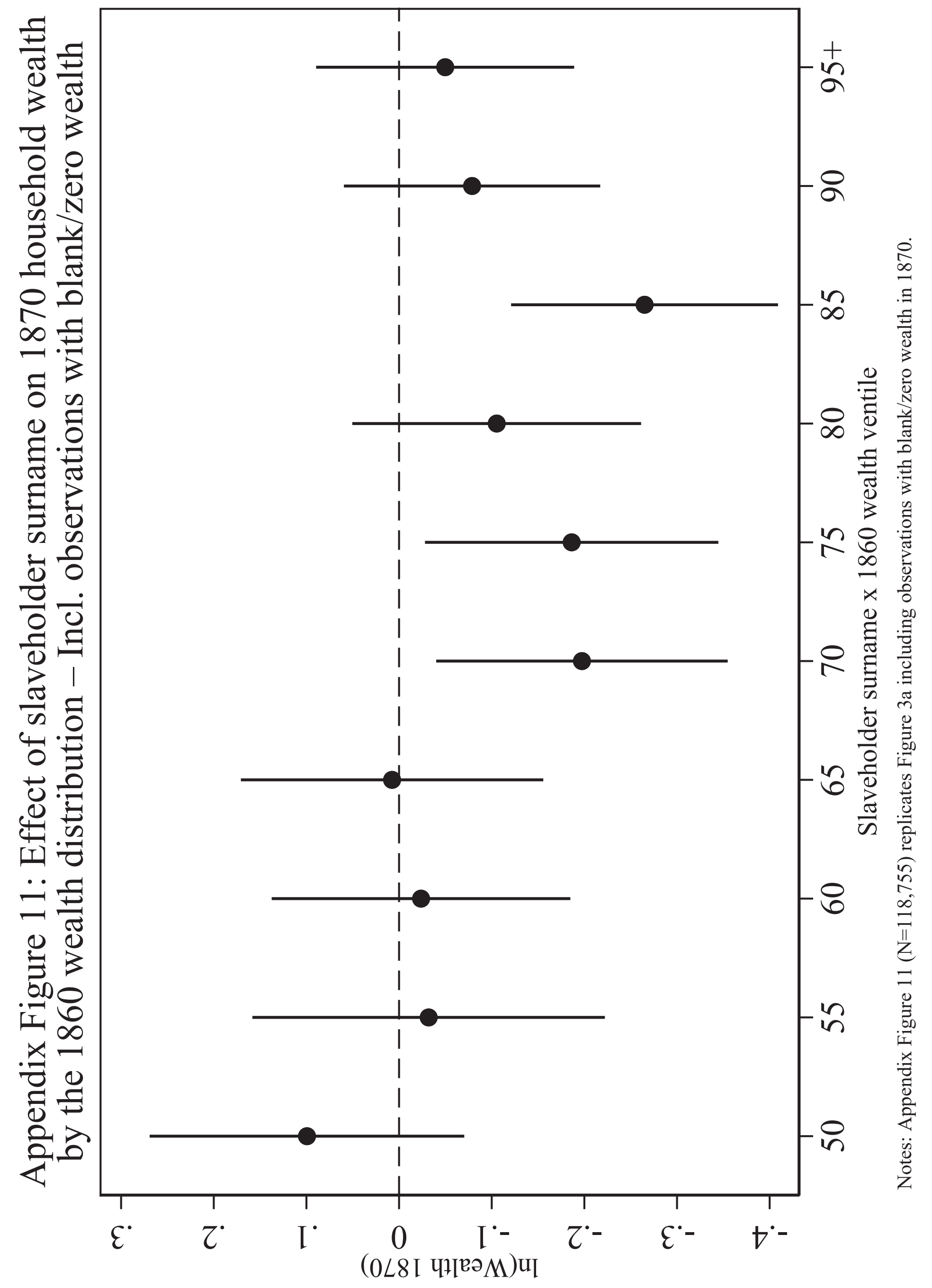




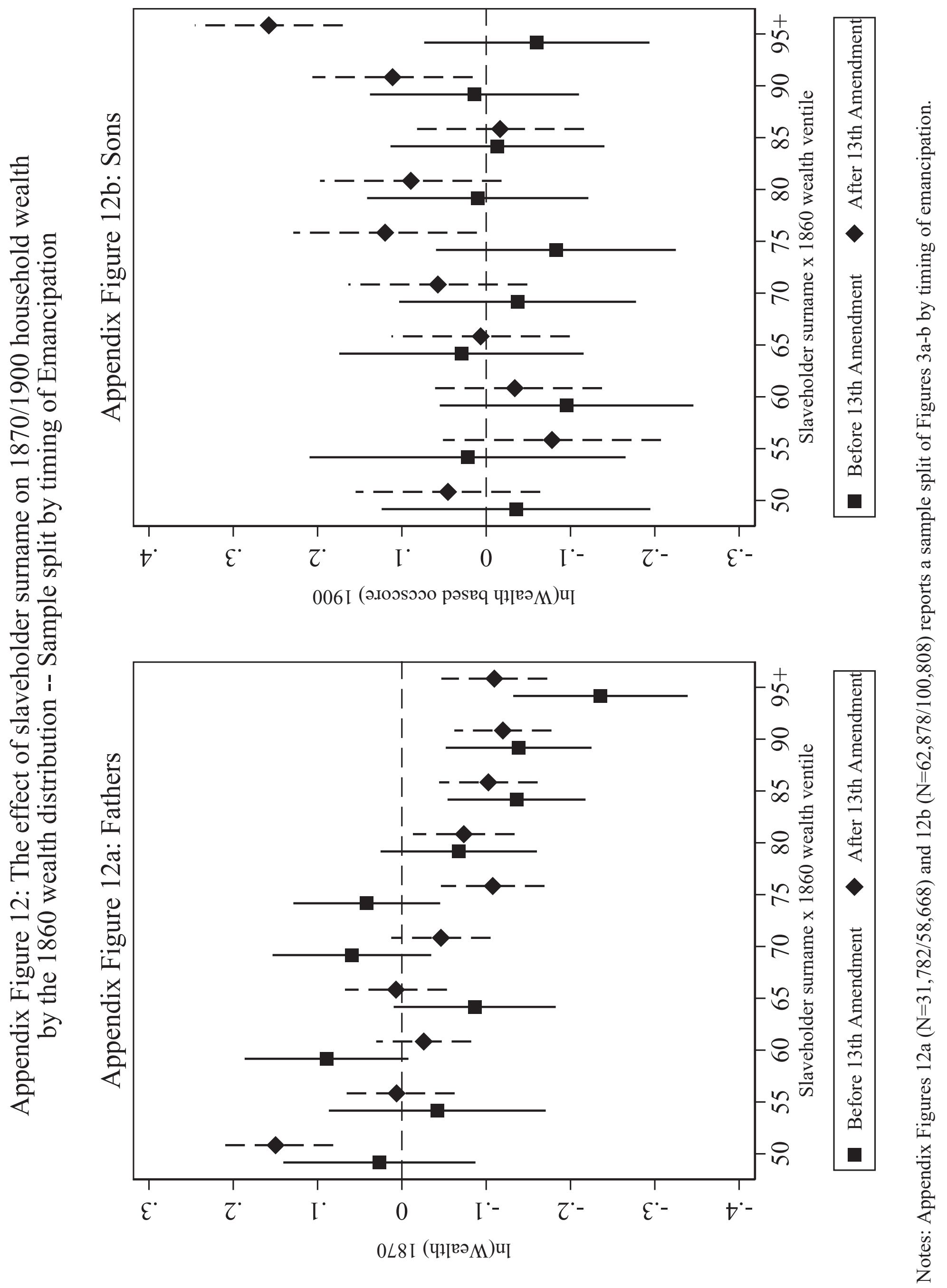




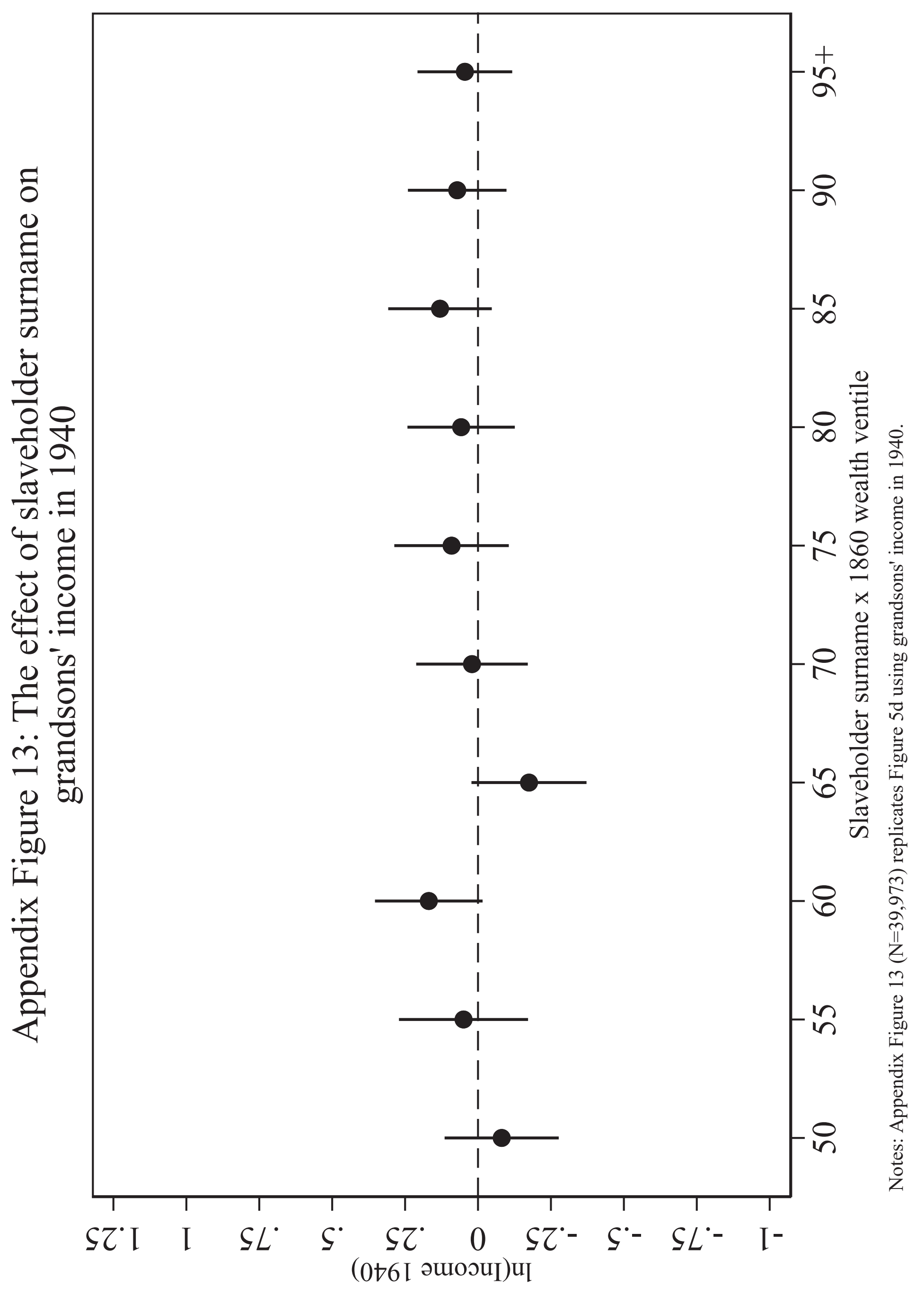




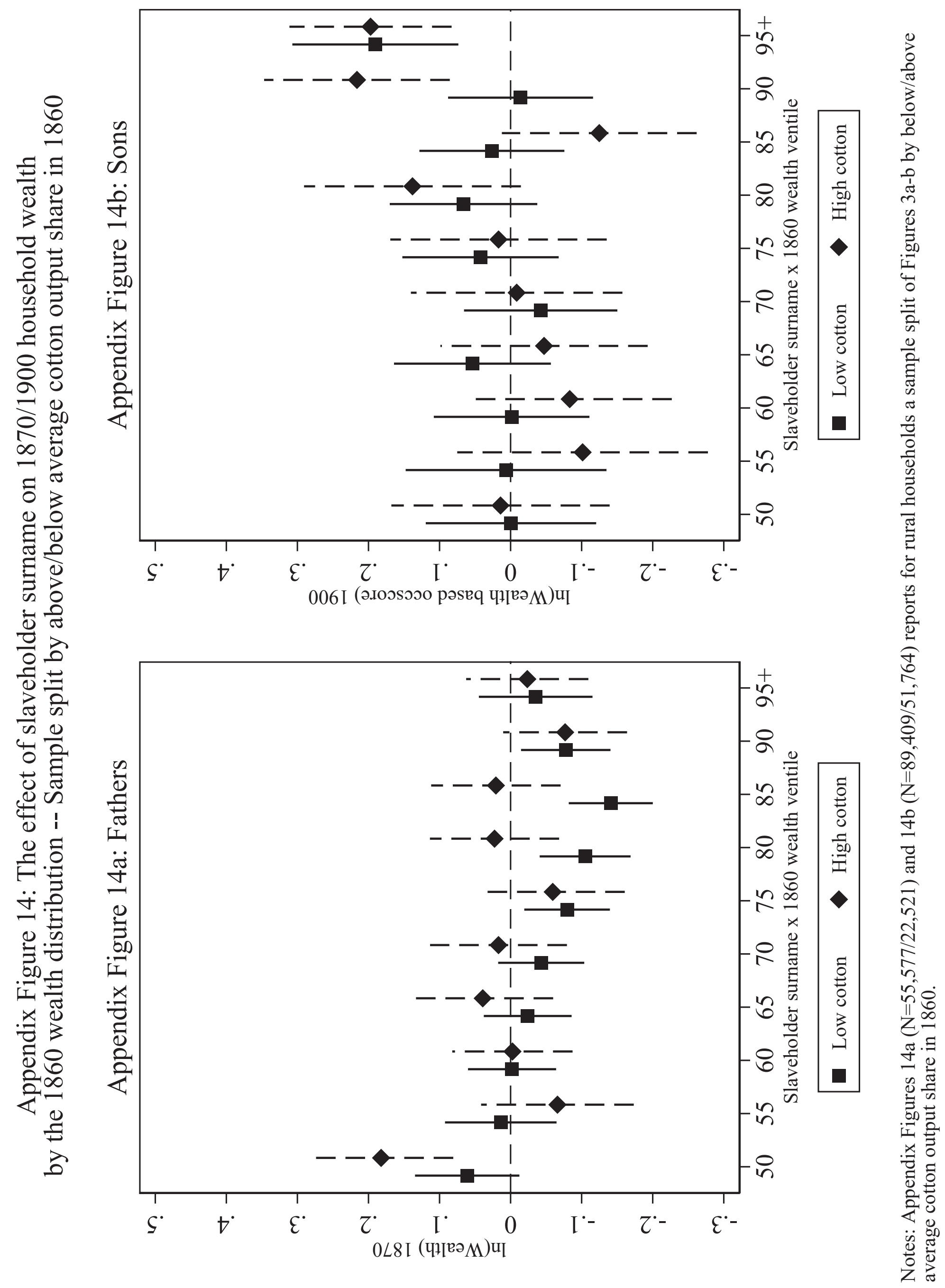




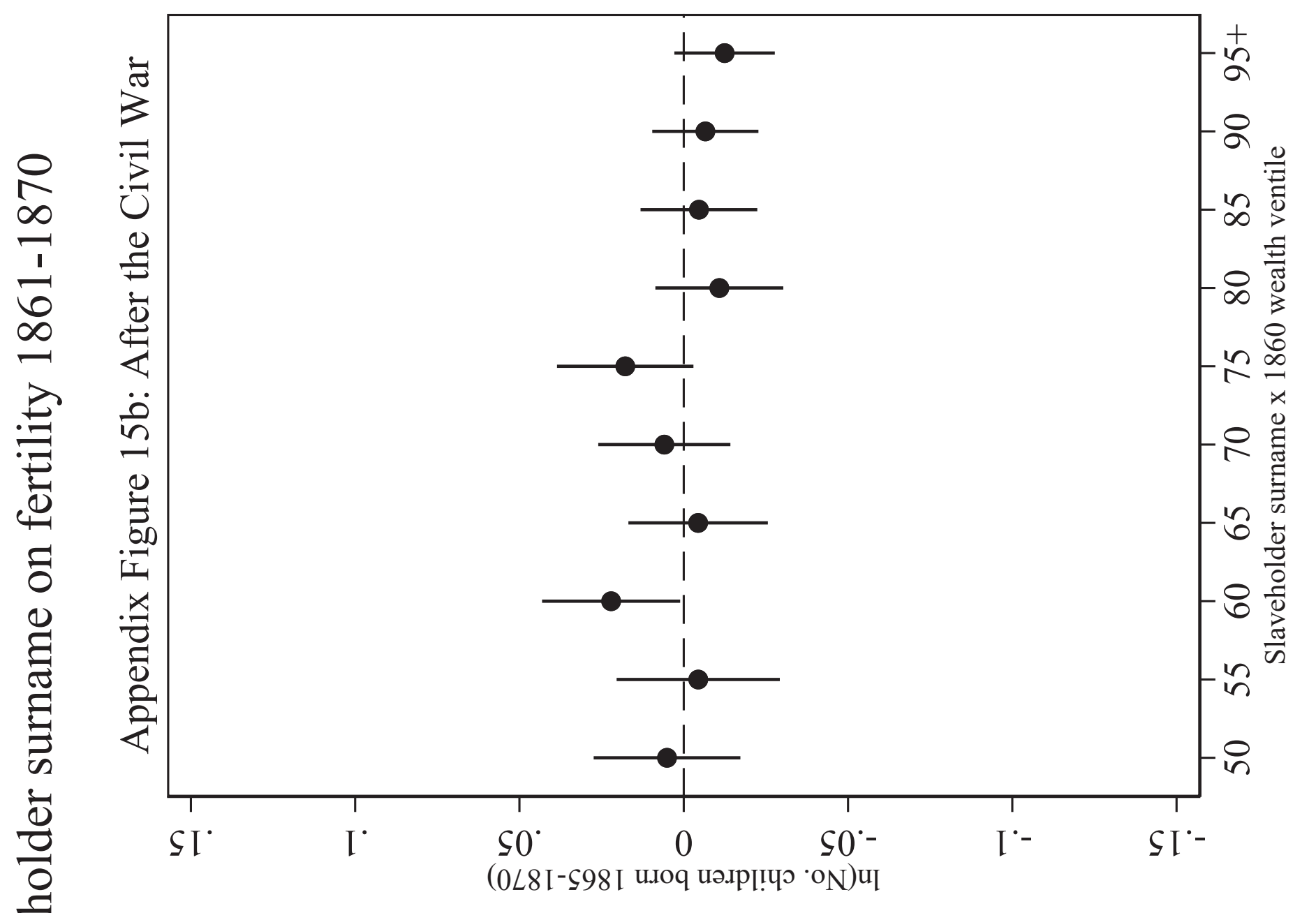

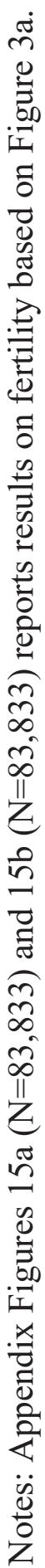




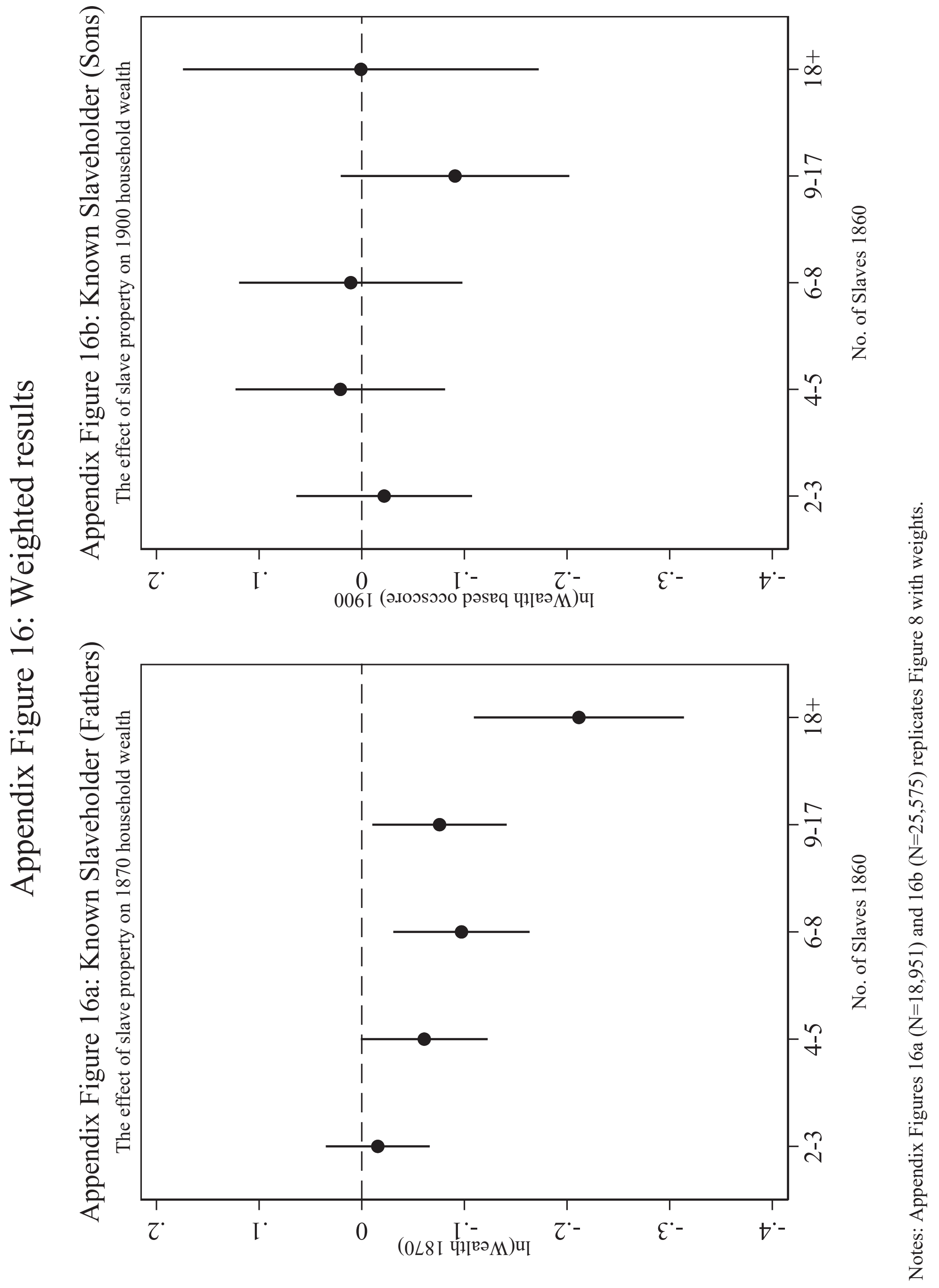


Appendix Table 1: Comparing the matched sample to the unmatched population in the 1860 Census

Coefficient on $=1$ if in matched sample

\begin{tabular}{l|ccc}
\hline Dependent variable & $\begin{array}{c}\text { Mean for } \\
\text { unmatched }\end{array}$ & Unweighted & Weighted \\
\hline Farmer & 0.532 & 0.060 & 0.003 \\
& & $(0.001)$ & $(0.001)$ \\
Age & 39.82 & 0.027 & -0.076 \\
& & $(0.034)$ & $(0.048)$ \\
Mean \# slaves by last name/state & 1.762 & 0.125 & -0.002 \\
& & $(0.008)$ & $(0.008)$ \\
\# sons & 1.482 & 0.145 & -0.007 \\
Percentile wealth distribution & & $(0.003)$ & $(0.004)$ \\
& 49.37 & 6.047 & 0.009 \\
Zero wealth & & $(0.070)$ & $(0.074)$ \\
& & -0.047 & -0.001 \\
Above 50th \%-ile wealth & 0.164 & $(0.001)$ & $(0.001)$ \\
& & 0.095 & 0.0002 \\
Above 90th \%-ile wealth & & $(0.001)$ & $(0.001)$ \\
Observations & & 0.038 & -0.001 \\
\hline
\end{tabular}

Notes: Sample includes all white male household heads in the South in 1860, including 200,000 cases that match forward to 1870 and remainder that do not. Each row reports coefficients from a regression of an 1860 father characteristic on an indicator for being in the matched sample. Column 1 shows unweighted results and column 2 instead weights by the propensity of being matched $\mathrm{P}_{i}\left(\mathrm{M}_{i}=1 \mid \mathrm{X}_{i}\right)$, which is calculated from a probit of match status on the covariates above $\left(\mathrm{X}_{i}\right)$. Observations are reweighted by $\left(1-\mathrm{P}_{i}\left(\mathrm{M}_{i}=1 \mid \mathrm{X}_{i}\right)\right) / \mathrm{P}_{i}\left(\mathrm{M}_{i}=1 \mid \mathrm{X}_{i}\right) \times q /(1-q)$, where $q$ is the proportion of records linked. 
Appendix Table 2: Summary statistics for southern fathers, sons and grandsons

Summary Statistics Southern Farthers -- 1860-1870

Wealth 1870

Real Estate Wealth 1870

Personal Estate Wealth 1870

Wealth-based Occupation Score (Fathers) 1870

Wealth 1860

Real Estate Wealth 1860

Personal Estate Wealth 1860

Age Father in 1860

Summary Statistics Southern Sons -- 1860-1900

Wealth-based Occupation Score (Sons) 1900

$==1$ if White Collar in 1900

Wife Wealth 1860

Wife Wealth 1870

Wealth 1860

Real Estate Wealth 1860

Personal Estate Wealth 1860

Age Son in 1860

Summary Statistics Southern Grandsons -- 1900-1940

Occupational Income Score (Grandsons) 1940

$==1$ if White Collar in 1940

$==1$ if ever in High School

$==1$ if ever in College

Wealth 1860

Real Estate Wealth 1860

Personal Estate Wealth 1860

Age Grandson in 1900

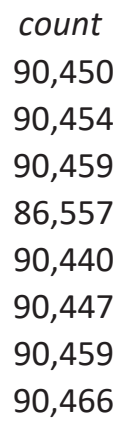

count

163,686

170,643

134,182

142,117

191,966

191,985

192,005

192,026

count

66,669

67,446

70,596

70,596

72,970

72,976

72,984

72,991 mean

120,605

83,420

37,180

11.88

$1,844,525$

503,078

$1,341,234$

42.80

mean

11.14

0.16

8.11

7.80

$2,838,309$

$1,943,348$

894,694

8.77

mean

3.13

0.32

0.39

0.13

333,689

155,190

178,489

9.91 sd

710,104

504,211

320,785

1.66

$331,842,228$

$114,485,919$

$310,579,867$

11.47

sd

2.56

0.37

1.47

1.05

$858,634,146$

$698,735,809$

$224,534,205$

5.41

sd

0.52

0.47

0.49

0.33

$6,948,058$

$4,232,129$

$5,302,986$

5.07 